\title{
Pivotal Advance: $\alpha$-Galactosylceramide induces protection against lipopolysaccharide-induced shock
}

\author{
Guido Sireci, ${ }^{*, 1}$ Marco P. La Manna, ${ }^{*}$ Caterina Di Sano, ${ }^{\dagger}$ Diana Di Liberto, ${ }^{*}$ Steven A. Porcelli, ${ }^{*}$ \\ Mitch Kronenberg, ${ }^{\S}$ Francesco Dieli, ${ }^{*}$ and Alfredo Salerno* \\ *Dipartimento di Biopatologia e Metodologie Biomediche, Università di Palermo, Palermo, Italy; ${ }^{\dagger}$ Istituto di \\ Biomedicina e Immunologia Molecolare, Consiglio Nazionale delle Ricerche, Palermo, Italy; ${ }^{\ddagger}$ Department of \\ Microbiology and Immunology, Albert Einstein College of Medicine, Bronx, New York, USA; and ${ }^{\S}$ La Jolla Institute \\ for Allergy and Immunology, San Diego, Calfornia, USA
}

Abstract: $\alpha$-galactosylceramide, a natural killer $\mathbf{T}$ cell ligand, and its synthetic homolog, KRN7000, consistently influence IFN- $\gamma$ and TNF- $\alpha$ release, both mediators of LPS-induced shock. To modify the course of endotoxin shock, we injected KRN7000 at different time points of experimental systemic Shwartzman reaction. Mice treated with KRN7000 survived when it was injected within $2 \mathrm{~h}$ before and after LPS challenge. Mice survival was associated with low levels of $T$ helper 1 (Th1) cytokines, such as IFN- $\gamma$ and TNF- $\alpha$. By contrast, protection from endotoxin shock was associated with an increase of $T$ helper 2 (Th2) cytokines, like IL-4 and IL-10. A role of Th2 cytokines in counteracting LPS-induced shock was supported by experiments in which the protection against Shwartzman reaction by KRN7000 was abrogated by in vivo coadministration of anti-Th2 cytokines antibodies. In addition, cytofluorimetric analysis showed that surviving animals have higher percentages of NKT-IL-10-positive cells and lower percentages of NKT-IFN- $\boldsymbol{\gamma}$ and macrophages/TNF$\alpha$-stained cells than nonprotected mice. Taken together, our data demonstrate that KRN7000 treatment given at times near LPS challenge is protective for endotoxin shock inhibiting IFN- $\gamma$ and TNF- $\alpha$ release. Moreover, KRN7000-mediated protection occurs through an increased production of IL-4 and IL-10, which are mainly secreted by NKT cells. Since IFN- $\gamma$ release by NKT requires a longer TCR stimulation than that required for Th2 cytokines production, we demonstrate that timing of KRN7000 in vivo exposure affect the pattern of cytokines expression protecting animals by endotoxin shock. J. Leukoc. Biol. 81: 607-622; 2007.

Key Words: rodent $\cdot$ cytokines $\cdot$ endotoxin

\section{INTRODUCTION}

Endotoxin shock is mainly caused by a huge systemic cytokine response to Gram-negative bacteria and their characteristic cell wall component, LPS. The uncontrolled production of Th1 cytokines causes several pathophysiological reactions, which ultimately form the endotoxic shock syndrome [1]. Because TNF- $\alpha$ and IFN- $\gamma$ have relevant roles in the lethality of experimental models of endotoxin shock, neutralization of these cytokines decreases mortality [1-6]. The critical role of these cytokines in the pathogenesis of LPS-induced shock was confirmed using mice deficient for either of their receptors [7-9]. Proinflammatory cytokines, in particular, TNF- $\alpha$ and IFN- $\gamma$, produced by machrophages [1] and $\mathrm{NK}^{+}$cells [10], play a key role in the disease pathogenesis.

$\mathrm{NK}^{+}$cells segregate in two major populations, namely, NKT and NK cells. NKT cells express the V $\alpha 14 / \mathrm{J} \alpha 281$ gene segments [1] and represent a $\mathrm{T}$ cell subset, which expresses NK cell markers such as NKR-Pl (NK1.1). NKT cells development depends on $\beta_{2}$-microglobulin- $\left(\beta_{2} \mathrm{~m}\right)$-associated CDld and hence, $\beta_{2} \mathrm{~m}^{-1-}$ mice lack most, but not all, CDl-restricted $\mathrm{T}$ cells belonging to this cell population [11-16]. Upon stimulation, $\mathrm{V} \alpha 14^{+}$NKT cells promptly secrete large amounts of the type 1 and 2 cytokines, IFN- $\gamma$, and IL-4, respectively [1]. NK cells develop independently of $\beta_{2} \mathrm{~m}$ and produce Thl and Th2 cytokines; both cell subsets are abundant in the liver [2].

Accumulating evidence suggests that NK cells participate in the pathogenesis of LPS-induced shock [17]. V $\alpha 14^{+}$NKT cells have been demonstrated by our group to play a central role in the pathogenesis of the generalized Shwartzman reaction [18] NKT cells are mainly involved in the Shwartzman reaction elicited by low doses of LPS, whereas NK cells play a prominent role at higher doses of LPS [18]. The relative contribution of NKT and NK cells might be variably dependent on the amount of IL-12 produced in response to the doses of LPS administered. It has been demonstrated that both NK and NKT cells constitutively express IL-12 receptor [19], although the expression on NKT cells was higher than that on NK cells [19]. Therefore, the large amount of IL-12 produced by injection of high doses of LPS in NKT-deficient mice might be sufficient to activate NK cells to overcome the impairment of NKT cells, which would be preferentially responsive to lower doses of IL-12 (and, by extension, of LPS).

\footnotetext{
${ }^{1}$ Correspondence: Dipartimento di Biopatologia e Metodologie Biomediche, Corso Tukory 211, Palermo 90134, Italy. E-mail: sireci@unipa.it

Received April 28, 2006; revised June 16, 2006; accepted August 1, 2006 doi: $10.1189 / \mathrm{jlb} .0506298$
} 
The glycolipid $\alpha$-Galactosylceramide ( $\alpha$-GalCer), originally isolated as a natural homolog from marine sponges [20], and its synthetic homolog, KRN7000, are specifically recognized by $\mathrm{V} \alpha 14^{+}$NKT cells. In vivo treatment with KRN7000 induces a Th2 or a Th0 cytokine response characterized by variable amounts of IFN- $\gamma$ and/or IL-4, depending on the time of in vivo exposure to KRN7000 [21, 22]. In particular, Singh et al. [21] reported that long-term exposure to KRN7000 (9 days) coadministered with ovalbumin, induced an antigen-specific switch from Th1 to Th2 cytokines production. Matsuda et al. [22] showed that KRN7000, given $2 \mathrm{~h}$ before animal euthanasia, induced a systemic release of IL-4, while $6 \mathrm{~h}$ of exposure induced an increase of IFN- $\gamma$. Moreover, NKT cells TCR down-regulation, induced by long in vivo exposure to KRN7000, has been recently demonstrated [23] to drive this subset to rapid expansion and sustained IFN- $\gamma$ production for several days after stimulation. Short exposure to $\alpha$-GalCer increases mRNA expression of IL-4, IL-2, IL- 6 , TNF- $\alpha$, and IL-10 in intrahepatic lymphocytes [24]. In particular, comparing plasmatic levels of cytokines with mRNA expression in liver lymphocytes after exposure to $\alpha$-GalCer, there are two substantial differences: 1) IFN- $\gamma$ mRNA precedes the plasma peak of $10 \mathrm{~h} ; 2$ ) in contrast to low plasmatic levels of IL-10, its mRNA expression is significantly increased $1 \mathrm{~h}$ after $\alpha$-GalCer treatment [24].

As KRN7000 administration significantly modifies the pattern of cytokines produced by NKT and transactivated NK, we thought that it could modify endotoxin shock outcome, inhibiting production of inflammatory cytokines (TNF- $\alpha$ and IFN- $\gamma$ ) and increasing Th2 cytokines (IL-4 and IL-10). We show in this report that KRN7000 administration a few hours before and after LPS challenge decreased lethality in the experimental systemic Shwartzman reaction, thus demonstrating its protective effects. These effects could be correlated with the inhibition of cytokines such as IFN- $\gamma$ and TNF- $\alpha$ and to an increased IL-4 and IL-10 production.

\section{MATERIALS AND METHODS}

\section{Animals}

C57BL/6 mice were purchased by Harlan-Nossan (Correzzana, MO, Italy). They were used at 8-12 wk of age. Each experimental group consisted of 30 male mice. Ten mice from each group were used to test survival to LPSinduced shock and aspartate aminotransferase/alanine aminotransferase (AST/ ALT) levels. Ten animals were used for cytokine assays and cytofluorimetric analysis. The remaining 10 mice were used to assess percentages of body weight loss.

\section{Induction of the experimental systemic Shwartzman reaction}

Mice were injected i.p. with $40 \mu \mathrm{g}$ of phenol-extracted Escherichia coli- or Salmonella typhimurium- or Salmonella abortus equi-derived LPS, purchased by Sigma-Aldrich (Milan, Italy). Twenty-four hours later, mice were challenged by intravenous injection of $400 \mu \mathrm{g}$ of LPS dissolved in $0.2 \mathrm{ml}$ of PBS [18]. Negative controls were injected with LPS priming dose and $0.2 \mathrm{ml}$ of PBS i.v. $24 \mathrm{~h}$ later or with $0.2 \mathrm{ml}$ of PBS i.p. and $24 \mathrm{~h}$ later with LPS challenge dose. The occurrence of systemic Shwartzman reaction was evaluated, monitoring animals' mortality for 7 days after challenge. Each batch of LPS was used to induce the reaction three times, and results reported in Tables 1-6, are the mean of three different experiments performed using one of the three different phenol-extracted preparations of LPS in each reaction. Body weights were recorded before priming and monitored over a period of $24 \mathrm{~h}$ after challenge. Data were represented as mean percent of control body weight $(100 \%)$. For in vivo blocking of cytokines, mice were injected i.p. $2 \mathrm{~h}$ before LPS challenge with $0.5 \mathrm{mg}$ of purified $\mathrm{mAb}$ against IL-4 (clone 11B11, rat IgG1; BD Biosciences, San Josè, CA, USA), or IL-10 (clone JES5-16E3, rat IgG1; BD Biosciences) or isotype control mAbs (rat IgG1, BD Biosciences).

\section{Serum transaminase}

Sera were collected $2 \mathrm{~h}$ after LPS challenge in mice treated with KRN7000 before challenge or $2 \mathrm{~h}$ after $\alpha$-GalCer administration in mice treated after challenge. Serum alanine aminotransferase (ALT; EC 2.6.1.2) and aspartate aminotransferase (AST; EC 2.6.1.1) were measured by the standard photometric method using an Hitachi type 7350 automatic analyzer (Hitachi chemical diagnostic, Freiburg, Germany) and a commercial kit (Sigma-Aldrich, Milan, Italy) adapted to small sample volumes [24]. As KRN7000 induces liver injury, we tested sera of mice treated with $\alpha$-GalCer only for AST and ALT levels. Sera were collected at the same times of LPS-KRN7000 treatment. $\alpha$-GalCerinduced AST and ALT levels were reported in Fig. 1. Normal range of AST and ALT was obtained testing sera from 10 C57BL/6 mice age- and sexmatched with animals treated with vehicle used for experimental groups.

\section{KRN7000 treatments}

$\alpha$-GalCer (KRN7000) was kindly provided by R\&D Collaboration Pharmaceutical Division, Kirin Brewery Co., Tokyo, Japan. It was injected in mice at indicated times at a dose of $4 \mu \mathrm{g}$ i.p. in $400 \mu \mathrm{l}$ of vehicle $(0.025 \%$ polysorbate), as suggested by Kirin; control mice received only the vehicle. For in vitro uses, KRN7000 was dissolved at the concentration of $10 \mathrm{ng} / \mathrm{ml}$ in RPMI 1640 medium containing $50 \mu \mathrm{M}$ 2-mercaptoethanol (2-ME), $2 \mathrm{mM} \mathrm{L-glu-}$ tamine, $100 \mathrm{U} / \mathrm{ml}$ penicillin/streptomycin, $10 \mathrm{mM}$ HEPES (GIBCO BRL, Grand Island, NY, USA) and supplemented with $10 \%$ heat-inactivated FCS (GIBCO BRL) (complete medium). Controls of $\alpha$-GalCer-induced cytokines production are spleen cells from mice primed, challenged with LPS, injected with KRN7000, and in vitro reexposed to vehicle (open triangles) and for

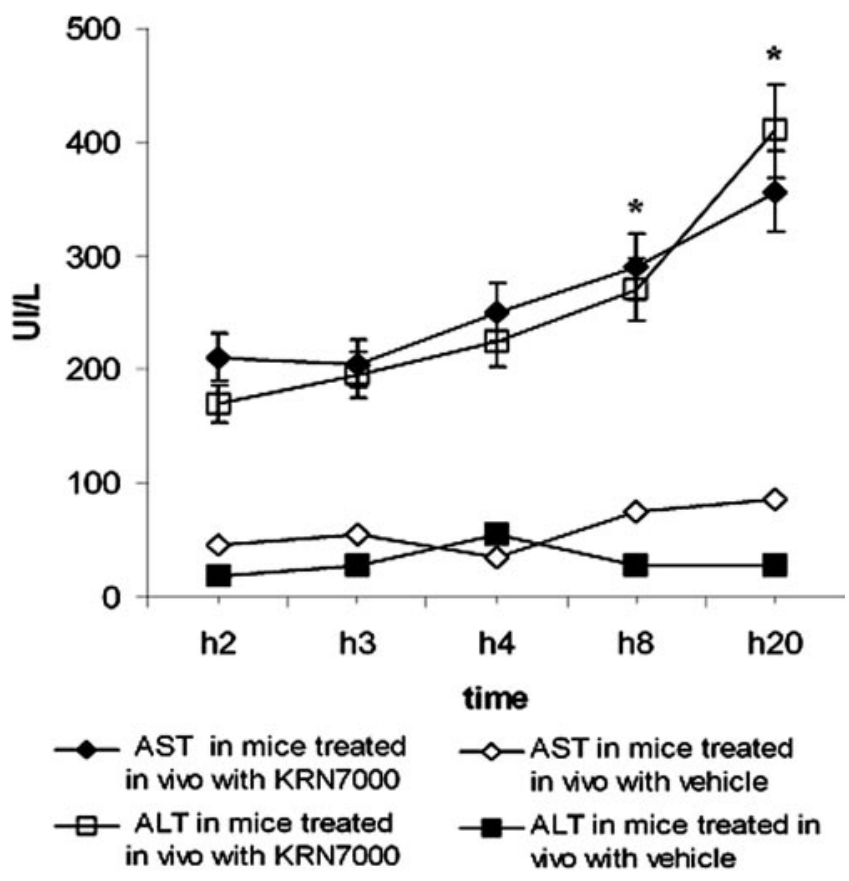

Fig. 1. Time course of $\alpha$-GalCer-induced AST and ALT release. Eight to twelve weeks old male C57BL/6 mice were injected i.p. with $4 \mu \mathrm{g}$ of $\alpha$-GalCer, diluted as described in Materials and Methods in vehicle, and sacrificed at indicated time points. AST $(\bullet)$ and ALT $(\square)$ activity were measured in plasma subsequently. Mice injected with the equal volume of vehicle were used as controls $(\diamond$ for AST or for ALT). The figure presents the summary of 3 independent experiments. 
IFN- $\gamma$ production (Figs. 3A and 5A) spleen cells obtained from mice in vivo primed and challenged with LPS plus vehicle and in vitro reexposed to $\alpha$-GalCer. Control cultures were set up using vehicle dissolved in complete medium.

\section{NKT- and NK-depletion}

Spleen cells from treated mice were incubated with $\alpha$-GalCer/mCDld-PElabeled tetramers using procedures suggested by La Jolla Institute of Allergy and Immunology. Cells were then incubated with anti-PE-microbeads (Miltenyi, Copenhagen, Denmark). Negative fraction was obtained by immunomagnetic separation using materials and procedures obtained by Miltenyi. $\mathrm{NKT}^{-}$ fractions were stained with $\alpha$-GalCer/mCDld-PE tetramers and checked by FACS analysis to test whether residual NKT cells are present in negative fractions. For NK-depletion, spleen cells were incubated with anti-TCR $\alpha \beta$ mAbs-PE-labeled (Clone H57-597, hamster IgG, Santa Cruz Biotechnology, Santa Cruz, CA, USA) for $15^{\prime}$ at $4^{\circ} \mathrm{C}$. After two washes in PBS, cells were incubated with anti-PE microbeads, and the negative and positive fraction were recovered (Miltenyi, Denmark). Negative fractions were incubated with pan-NK microbeads (DX5-coated microbeads, Miltenyi). Negative fraction was recovered after immunomagnetic separation using materials and procedures obtained by Miltenyi. Purification of $\mathrm{NK}^{-}$and $\mathrm{NKT}^{-}$fractions were $85-90 \%$, as determined by FACS. The $\mathrm{NK}^{-}$fractions were reconstituted with TCR $\alpha \beta^{+}$ fractions to obtain spleen cells depleted only of NK. $\mathrm{NKT}^{-} \mathrm{NK}^{-}$fractions were obtained by immunomagnetic negative separation for NKT followed by negative separation for NK. $4 \times 10^{5}$ well unfractionated spleen cells and derived $\mathrm{NKT}^{-}, \mathrm{NK}^{-}$, and $\mathrm{NKT}^{-}-\mathrm{NK}^{-}$were reexposed in vitro to KRN7000 and used for cytokines production as described below.

\section{Cytokines production}

$4 \times 10^{5}$ cells per well were incubated with or without $10 \mathrm{ng} / \mathrm{ml}$ of KRN7000 in complete medium for $60 \mathrm{~h}$ at $37^{\circ} \mathrm{C}$ in $5 \% \mathrm{CO}_{2}$ atmosphere. For measurement of cytokines levels, either in serum samples or in culture supernatants, we used IFN- $\gamma$, IL-4, IL-10, and TNF- $\alpha$ Quantikine Mouse ELISA kits (R\&D Systems, Minneapolis, MN, USA). Detection limits were 5.1 and $4 \mathrm{pg} / \mathrm{ml}$. Serum samples were collected after $1 \mathrm{~h}$ for TNF- $\alpha, 6 \mathrm{~h}$ for IFN- $\gamma$, or $2 \mathrm{~h}$ from LPS challenge for IL-10 [25]. Data obtained in sera collected at different time points always confirm the differences existing between LPS-KRN7000 and LPS vehicletreated animals showed in Figs. 2 and 4. Control groups are sex- and agematched mice treated with LPS and vehicle at the same time points of KRN7000. Sera and supernatants from each experimental or control group were collected by at least 10 mice. Each experimental or control group for serum and culture supernatant cytokine content was repeated three times with less than $10 \%$ of differences between each test. Data reported represent the mean of three different experiments.

\section{Preparation of liver mononuclear cells}

Liver mononuclear cells were prepared as described [18]. In brief, livers were minced, passed through a mesh, and suspended in complete RPMI 1640. Cells were resuspended in 30\% Percoll containing $100 \mathrm{U} / \mathrm{ml}$ heparin and centrifuged at 2,000 rpm for $20 \mathrm{~min}$ at room temperature.

\section{Intracellular cytokines detection}

After we isolated intracellular cytokines from liver and spleen, the cells were stained and cultured for $6 \mathrm{~h}$ in $3 \mu \mathrm{M}$ of Monensin (Sigma-Aldrich, Milan, Italy). Lymphocytes were incubated in PBS $0.1 \% \mathrm{NaN}_{3}$ with anti-mouse CD16/32 mAb (clone 2.4G2) (BD Biosciences) at the mAb and cell concentration, indicated by manufacturer, for $5^{\prime}$ at $4^{\circ} \mathrm{C}$ to avoid nonspecific binding to FcR $\gamma$ s. Cells were labeled with F4/80-PE-conjugated (CLA3-1, rat IgG2b, Serotec, Oxford, UK). For separation of F4/80 positive cells, anti-PE-microbeads (Miltenyi) were added, and positive fractions were collected by immunomagnetic methods (Miltenyi, Copenhagen, Denmark). After surface stainings, cells were harvested and fixed with $4 \%(\mathrm{wt} / \mathrm{vol})$ paraformaldehyde (Sigma-Aldrich) in PBS for 10 min at room temperature. For intracytoplasmic staining, fixed cells were resuspended and washed twice with permeabilization buffer containing $0.1 \%$ saponin (Sigma-Aldrich), $1 \%$ heat-inactivated FCS and $0.1 \% \mathrm{NaN}_{3}$ in PBS. To analyze cytokines in TCR down-regulated NKT, permeabilized cells were incubated with mCDld- $\alpha-$ GalCer-PE-labeled tetramers or mCDld-unloaded-PE-labeled, as negative control, after staining for intracellular cytokines. Permeabilized cells were incubated with FITC-conjugated anti-mouse IFN- $\gamma$ mAb (clone XMG1.2, rat IgG1; BD Biosciences) or FITC-conjugated anti-mouse IL-4 (clone 11B11, rat IgG1; BD Biosciences) or FITC-conjugated anti-mouse IL-10 (clone JES5-16E3, rat IgG1; BD Biosciences) or FITC-conjugated anti-mouse TNF- $\alpha$ mAb (clone MP6-XT22, rat IgG1; BD Biosciences). As control, FITC-conjugated isotype mAbs (clone R3-34, rat IgG1; BD Biosciences) were used. Cells were analyzed with a FACScanTM flow cytometer (Becton Dickinson, San Josè, CA, USA). Viable cells were gated by forward and sidescatter; analysis was performed on 100,000 acquired events for each sample.

\section{Statistics}

The $\chi^{2}$ and the Student's $t$ test were used to compare significance of differences between experimental and control groups.

\section{RESULTS}

\section{KRN7000 protects mice from systemic Shwartzman reaction}

We investigated whether KRN7000, injected at different time points before and after LPS challenge, could protect mice against endotoxin shock.

Percentages of mortality, transaminase, and body weight loss in phenol-extracted E. coli LPS-induced shock in C57BL/6 mice were determined. Mice were divided into positive controls (animals primed and challenged with LPS), negative controls (animals primed or challenged only), experimental groups treated with KRN7000 1, 1.5, 2, 6, or $18 \mathrm{~h}$ before LPS challenge and their control groups treated with LPS + vehicle at the same time points. All C57BL/6 mice survived when treated with KRN7000 within $2 \mathrm{~h}$ before challenge (Table 1), while groups treated 6 or $18 \mathrm{~h}$ before challenge did not survive. Similar results were obtained with highly purified S. abortus equi- or $S$. typhimurium-derived LPS (data not shown), verifying that the reaction was induced by LPS but not other contaminating components, such as lipoprotein, present in commercially obtained LPS [25, 26]. Additionally, liver injury assessed by transaminase levels revealed less AST and ALT in the sera of KRN7000-protected mice (animals treated within $2 \mathrm{~h}$ before challenge) than in nonprotected animals (mice treated 6 or $18 \mathrm{~h}$ before LPS challenge). Another parameter used to evaluate LPS-induced shock was the assessment of body weight loss, due to severe dehydration and diarrhea occurring during Shwartzman reaction. In nonprotected mice, we observed considerable loss of body weight $(8-12 \%)$ compared with animals protected against endotoxin shock by KRN7000 treatments $(0-1 \%)$. No protection against endotoxin shock was observed in control groups mock-injected without KRN7000 (data not shown).

To analyze the effects of KRN7000 in LPS-challenged mice, we performed experiments shown in Table 2 with mice treated with KRN7000 $30 \mathrm{~min}, 1,2$, and $3 \mathrm{~h}$ after LPS challenge. Assessment of mortality, scored within $1 \mathrm{wk}$ from challenge, as shown in Table 2, revealed that C57BL/6 mice, treated within $2 \mathrm{~h}$ after challenge, survived to LPS-induced shock, while mice treated $3 \mathrm{~h}$ after challenge died. Surviving mice had lower AST/ALT levels compared with nonprotected animals. In addition, nonprotected animals lost higher percentages of weight when compared with protected animals. 
TABLE 1. KRN7000's Effects in Systemic Shwartzman Reaction: Treatments Before LPS Challenge

\begin{tabular}{|c|c|c|c|c|c|}
\hline $\begin{array}{l}\text { Hours before LPS } \\
\text { challenge }\end{array}$ & Deaths/tested & Mortality $\%$ & AST U/L & AST U/L & $\begin{array}{c}\text { Percent of body } \\
\text { weight loss }\end{array}$ \\
\hline Positive controls ${ }^{a}$ & $9 / 10$ & 90 & $538 \pm 101$ & $2034 \pm 309$ & 9 \\
\hline Negative controls ${ }^{b}$ & $0 / 10$ & 0 & $129 \pm 30$ & $48 \pm 13$ & 0 \\
\hline Negative controls ${ }^{c}$ & $0 / 10$ & 0 & $346 \pm 36$ & $437 \pm 35$ & 0 \\
\hline 1 & $0 / 10$ & 0 & $428 \pm 25^{*}$ & $413 \pm 155^{*}$ & 0 \\
\hline 1.5 & $0 / 10$ & 0 & $434 \pm 35^{*}$ & $419 \pm 120 *$ & 1 \\
\hline 2 & $0 / 10$ & 0 & $423 \pm 44^{*}$ & $515 \pm 65^{*}$ & 1 \\
\hline 6 & $10 / 10$ & 100 & $730 \pm 105$ & $2042 \pm 306$ & 12 \\
\hline 18 & $10 / 10$ & 100 & $1345 \pm 151$ & $1848 \pm 63$ & 8 \\
\hline
\end{tabular}

Results shown were obtained with phenol-extracted $E$. coli LPS and reproduced using LPS from S. typhimurium or S. abortus equi. Two hours after challenge, mice were bled and sera were collected by centrifugation for transaminases. Body weights were recorded before and $24 \mathrm{~h}$ after challenge. Data are represented as mean percentages of control body weight (100\%) over $24 \mathrm{~h}$. Data are represented as mean percent of control body weight (100\%) over $24 \mathrm{~h}$. All AST and ALT data represent mean values \pm SE obtained from 10 animals. Experiments were repeated 3 times with reproducible outcome. Normal range $( \pm 2$ SD) AST $=54-170$ U/L, Normal range ALT $=32-114 \mathrm{U} / \mathrm{L}$. This range was obtained from a pool of sera obtained from sex- and age-matched C57BL/6. $* P<0.001$ by the $\chi^{2}$ test when data obtained from experimental groups were compared to control groups. ${ }^{a}$ Positive controls: LPS primed and challenged mice as reported in Materials and Methods. ${ }^{b}$ Mice were primed with LPS, as described in Materials and Methods, and $24 \mathrm{~h}$ later received $0.2 \mathrm{ml}$ of PBS i.v. ${ }^{c}$ Mice were injected with $0.2 \mathrm{ml}$ of PBS i.p. and $24 \mathrm{~h}$ later challenged with LPS, as described in Materials and Methods section.

Thus, KRN7000 treatment is able to prevent the fatal outcome of an experimental systemic Shwartzman reaction when administered a few hours before and after LPS challenge. Protection by KRN7000 occurs only when there is a short in vivo exposure (no more than $2 \mathrm{~h}$ before and after challenge).

\section{Protection correlates with decrease of Th1 and increase of Th2 cytokines}

Because of the possible contribution of endogenous TNF- $\alpha$, IFN- $\gamma$, and IL-10 to LPS-induced shock [18, 25], the systemic release of these cytokines was analyzed in mice treated with KRN7000 before LPS-challenge. Sera were collected 1 (TNF$\alpha), 2$ (IL-10), and $6 \mathrm{~h}$ (IFN- $\gamma$ ) after LPS challenge to detect the peak of systemic cytokines production. Figure 2 shows a statistically significant increase of serum TNF- $\alpha$ (Fig. 2A) and IFN- $\gamma$ (Fig. 2B) levels detected in mice treated 6 or $18 \mathrm{~h}$ before challenge while in the other groups treated within $2 \mathrm{~h}$ before challenge, TNF- $\alpha$ and IFN- $\gamma$ were reduced with respect to control levels. Serum IL-10 levels (Fig. 2C) were higher in protected KRN7000-treated mice but lower in nonprotected animals when compared with controls. Differences between LPS-KRN7000 and LPS-vehicle-treated animals were reproduced without significant differences when tested sera were collected at different time points following LPS challenge (data not shown).

The modulation of the cytokine responses in mice treated with KRN7000 before challenge was confirmed testing IFN- $\gamma$, IL-4, and IL-10 produced after in vitro reexposure to $\alpha-$ GalCer of splenocytes obtained by treated animals. In fact, we showed that IFN- $\gamma$ levels in culture supernatants were lower in protected mice (1, 1.5, and $2 \mathrm{~h}$ before challenge, Fig. 3A) when compared with supernatants obtained by spleen cells from nonprotected animals ( 6 and $18 \mathrm{~h}$ before LPS challenge). As controls, we used spleen cells from in vivo LPS-KRN7000treated mice in vitro reexposed to vehicle (open triangles), and for IFN- $\gamma$, we used also lymphocytes from mice primed and challenged with LPS plus vehicle and reexposed in vitro to KRN7000 (open circles). IL-4 production reached one peak at

TABLE 2. KRN7000's Effects in Systemic Shwartzman Reaction: Treatments After LPS Challenge

\begin{tabular}{|c|c|c|c|c|c|}
\hline Positive controls ${ }^{a}$ & $9 / 10$ & 90 & $838 \pm 115$ & $2034 \pm 30$ & 10 \\
\hline Negative controls ${ }^{c}$ & $2 / 10$ & 20 & $329 \pm 73$ & $418 \pm 37$ & 1 \\
\hline 3 & $10 / 10$ & 100 & $1348 \pm 120$ & $1354 \pm 58$ & 11 \\
\hline 2 & $0 / 10$ & 0 & $590 \pm 18 *$ & $711 \pm 15^{*}$ & 0 \\
\hline
\end{tabular}

Results shown were obtained with phenol-extracted $E$. coli LPS and reproduced using LPS from S. typhimurium or S. abortus equi. Two hours after challenge for LPS-treated groups or $2 \mathrm{~h}$ after administration of $\alpha$-GalCer (as described in Materials and Methods) mice were bled and sera collected by centrifugation to test transaminases and systemic cytokines. Body weights were recorded before and $24 \mathrm{~h}$ after challenge. Data are represented as mean percentages of control body weight $(100 \%)$ over $24 \mathrm{~h}$. All AST-ALT results represent mean values \pm SE from five to eight animals. Experiments were repeated 3 times with consistent outcome. Normal range $( \pm 2 \mathrm{SD})$ AST $=54-170 \mathrm{U} / \mathrm{L}$; normal range ALT $=32-114 \mathrm{U} / \mathrm{L}$. This range was obtained from a pool of sera obtained from sex- and age-matched C57BL/6 mice. $* P<0.001$ by the $\chi^{2}$ test when data obtained from experimental groups were compared to control groups. ${ }^{a}$ Positive controls: LPS primed and challenged mice as reported in Materials and Methods. ${ }^{b}$ Mice were primed with LPS, as described in Materials and Methods, and $24 \mathrm{~h}$ later received $0.2 \mathrm{ml}$ of PBS i.v. ${ }^{c}$ Mice were injected with $0.2 \mathrm{ml}$ of PBS i.p. and $24 \mathrm{~h}$ later challenged with LPS, as described in Materials and Methods. 

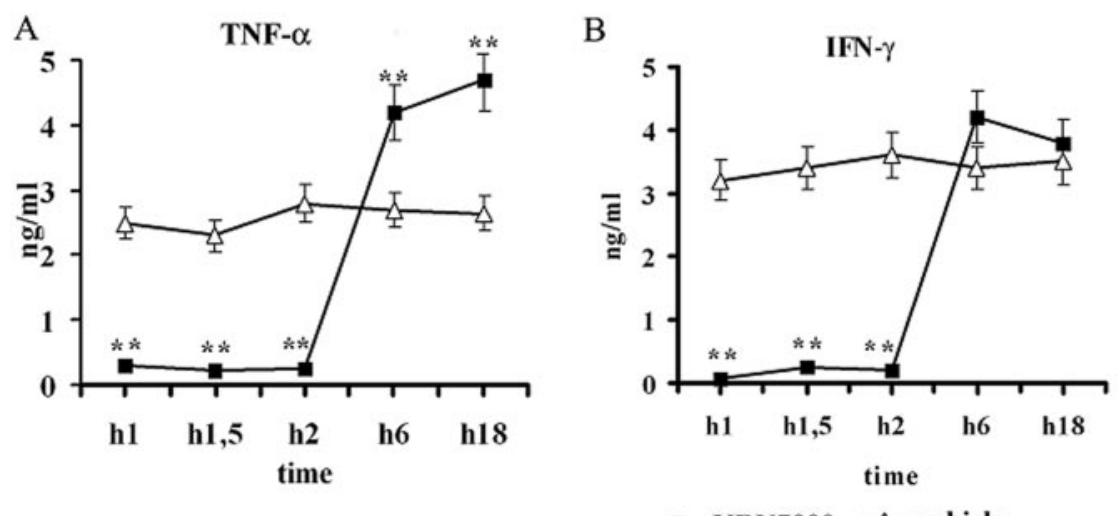

$\mathrm{C}$

KRN7000 $\triangle-$ vehicle

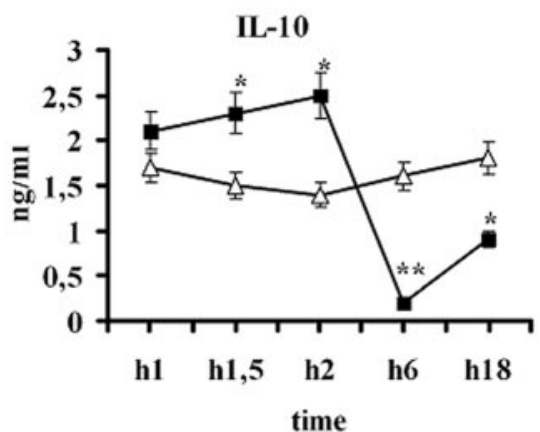

Fig. 2. Cytokines levels in sera of mice treated with KRN7000 before challenge. Groups of 10 mice were injected with KRN7000 or vehicle only from 1 to $18 \mathrm{~h}$ before LPS challenge. Sera were collected from 10 mice of each group $1 \mathrm{~h}$ after challenge for TNF- $\alpha$ (A), $6 \mathrm{~h}$ after challenge for IFN- $\gamma$ (B), and $2 \mathrm{~h}$ after challenge for IL-10 assay (C) (ם). Data reported are the means of serum cytokines content tested for each animal of any group. Differences from cytokines levels detected in controls and experimental groups were reproduced without significant modifications when tested sera were collected at different time points following LPS challenge (data not shown). Serum cytokine levels were determined by ELISA. Data are the means of three different experiments. Before LPS challenge, the above cytokines were undetectable in the sera. Open triangles $(\Delta)$ represent the values obtained from mice treated with LPS plus vehicle at the same times of experimental groups treated before challenge. In these control groups, sera were collected after challenge at the same times of experimental groups. $* *, P<0.001 *, P<0.05$.

A

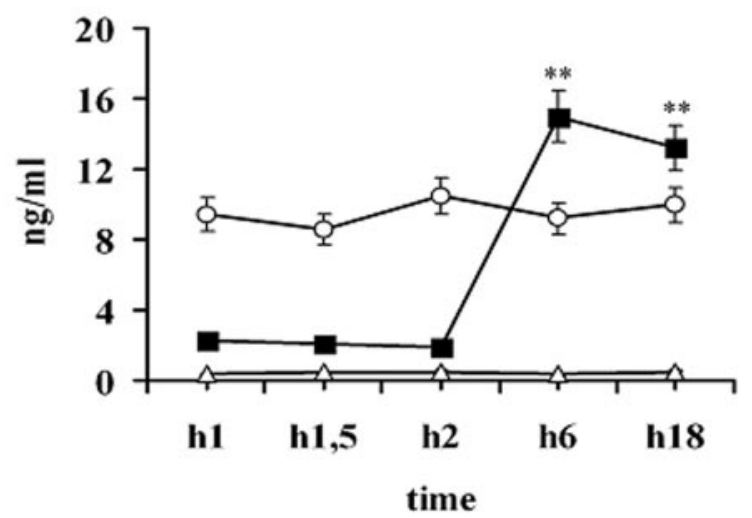

C

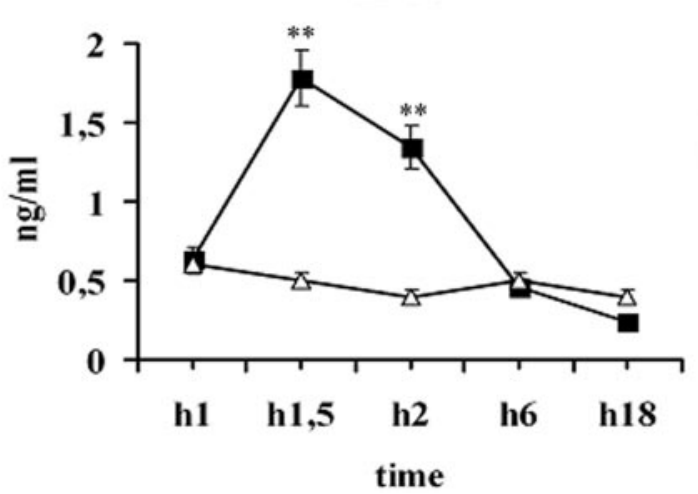

B

IL-4

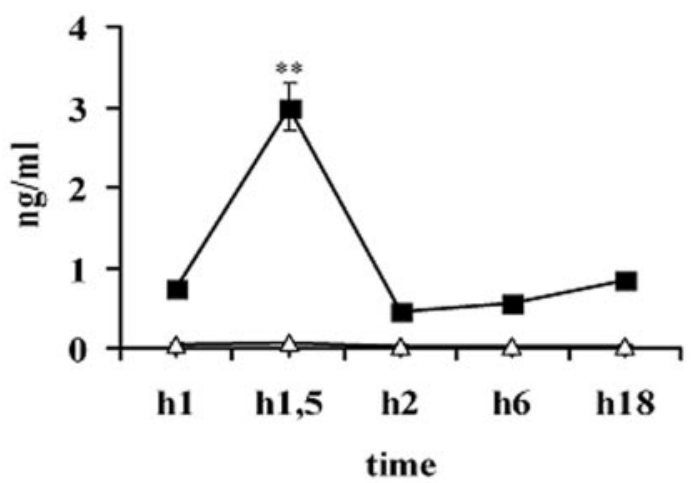

time

LPS - KRN7000 in vivo KRN7000 in vitro

$-\leftarrow$ LPS - KRN7000 in vivo veichle in vitro

-o- LPS - veichle in vivo KRN7000 in vitro

Fig. 3. Cytokine production by spleen cells from LPS-KRN7000-treated mice before challenge and reexposed in vitro to $\alpha$-GalCer. C57BL/6 mice were injected with KRN7000 or with vehicle at indicated times before LPS challenge. $2 \mathrm{~h}$ after LPS challenge, groups of 10 mice were sacrificed. Pooled spleen cells from each

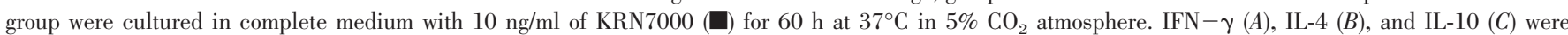
measured in culture supernatants by ELISA. Open triangles $(\Delta)$ represent the levels of cytokines in mice treated with LPS-KRN7000 at the same times of previously showed experimental groups treated before challenge, and spleen cells were reexposed in vitro to vehicle. (A) Open circles (O) represent the levels of cytokines produced by splenocytes of mice treated with LPS and vehicle and reexposed in vitro to $\alpha$-GalCer. Results reported are the means of 3 different experiments. **, $P<0.001$. 
$1.5 \mathrm{~h}$ before LPS challenge, and this level was higher than control (Fig. 3B). IL-10 produced by mice treated with KRN7000 1.5 or $2 \mathrm{~h}$ before challenge was increased when compared with controls and decreased to values obtained from controls in mice treated 6 and $18 \mathrm{~h}$ before LPS challenge (Fig. 3C).

To investigate whether a similar modification of the pattern of cytokines production was also observed in mice protected from endotoxin shock by KRN7000 treatment after LPS challenge, we tested serum cytokines levels in mice treated with $\alpha$-GalCer $30 \mathrm{~min}, 1,2$, and $3 \mathrm{~h}$ after challenge. Figure 4 shows that serum TNF- $\alpha$ (A) and IFN- $\gamma$ levels (B) were significantly lower in mice protected against endotoxin shock by KRN7000 treatment within $2 \mathrm{~h}$ of LPS challenge and higher in animals treated with KRN7000 $3 \mathrm{~h}$ after challenge. Figure 4C describes IL-10 systemic concentrations: IL-10 levels were higher in protected animals and lower in nonprotected mice when compared with controls.

Cytokine responses in mice treated with KRN7000 after challenge were tested also in culture supernatants obtained by splenocytes of LPS/KRN7000-treated mice and in vitro reexposed to $\alpha-$ GalCer. IFN- $\gamma$ levels in splenocyte supernatants were low in protected mice ( $30 \mathrm{~min}, 1$ and $2 \mathrm{~h}$ after challenge, Fig. 5A) and high (3 h after challenge) in spleen cells of non protected animals. Controls are spleen cells of mice treated with LPS/KRN7000 in vivo and re-exposed in vitro to vehicle (open triangles) and lymphocytes obtained from mice treated with LPS and vehicle in vivo and reexposed in vitro to $\alpha$-GalCer (open circles). IL-4 production reached one peak at $1 \mathrm{~h}$ after LPS challenge (Fig. 5B). IL-10 levels were significantly higher in mice treated with KRN7000 within $2 \mathrm{~h}$ and decreased in mice treated $3 \mathrm{~h}$ after LPS challenge (Fig. 5C).

In Fig. $\mathbf{6}$ are reported data of cytokines production by NKT', $\mathrm{NK}^{-}$, $\mathrm{NKT}^{-}-\mathrm{NK}^{-}$, or unseparated spleen cells obtained from protected (A) or nonprotected (B) animals to analyze how NK, NKT, or both cell types contributes to the interleukins production in our experimental model. We choose as representatives two groups of KRN7000-protected animals (1.5 h before challenge and $1 \mathrm{~h}$ after challenge) and two groups of nonprotected mice (18 h before challenge and $3 \mathrm{~h}$ after challenge). In surviving mice (A), NKT negative fractions produced lower levels of IL-4 and IL-10 when compared with undepleted or $\mathrm{NK}^{-}$splenocytes after in vitro reexposure to KRN7000. In nonprotected mice, IFN- $\gamma$ was produced under control of NK and NKT cells. In fact, $\mathrm{NK}^{-}$and $\mathrm{NKT}^{-}$fractions from nonprotected mice produce less IFN- $\gamma$ than unseparated spleen cells (Fig. 6B), suggesting that NK and NKT contribute almost equally to IFN- $\gamma$ production.

These data suggest that Th2 cytokines production is mainly due to short $\mathrm{T}$ cell receptor stimulation of NKT with little contribution from NK cells. By contrast, long $\mathrm{T}$ cell receptor stimulation ( $>2 \mathrm{~h}$ of $\alpha$-GalCer exposure) induces IFN- $\gamma$ production by NKT and transactivated NK cells.

\section{Anti-IL-10 and anti-IL-4 in vivo injection modify KRN7000 protection by endotoxin shock}

To confirm the role of Th2 cytokines in KRN7000-mediated protection against LPS induced shock, we injected a neutralizing anti-IL10 $\mathrm{mAb} 2 \mathrm{~h}$ before challenge to test whether protection by $\alpha$-GalCer was due to IL-10 production. The effects of anti-IL-10 mAb administration were determined in our experimental models of mice treated with KRN7000 either before (Table 3) or after endotoxin challenge (Table 4).

Our data, shown in Tables 3 and 4, indicate that the action of KRN7000 in LPS-induced shock is inhibited after IL-10 neutralization, as most mice succumbed to endotoxin shock when anti-IL10 mAbs was coadministered in KRN7000-protected groups (data in bold in Table 3 and 4). Assessment of serum transaminase activity and weight loss supports percentages of mortality data. $\alpha$-GalCer-induced protection wasn't modified by isotype control mAbs treatment (data in brackets).

Tables 5 and $\mathbf{6}$ describe protection against endotoxin shock induced by KRN7000, which can also be reverted by anti-IL-4 mAbs treatments either after priming (Table 5) or after chal-
A

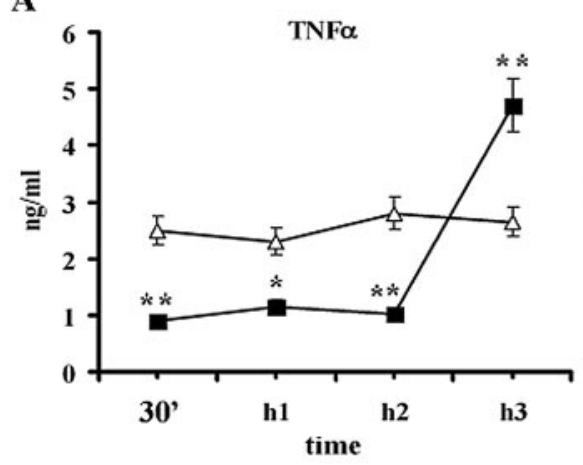

B

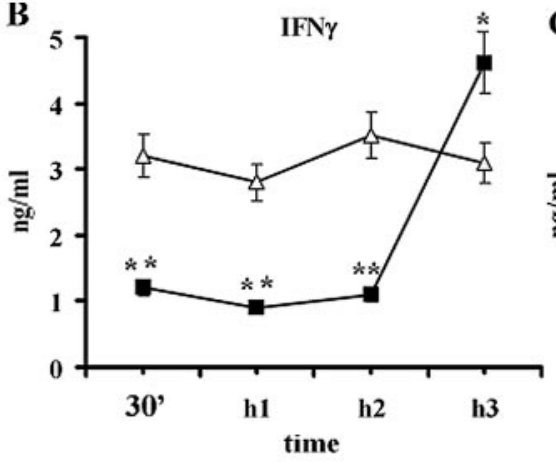

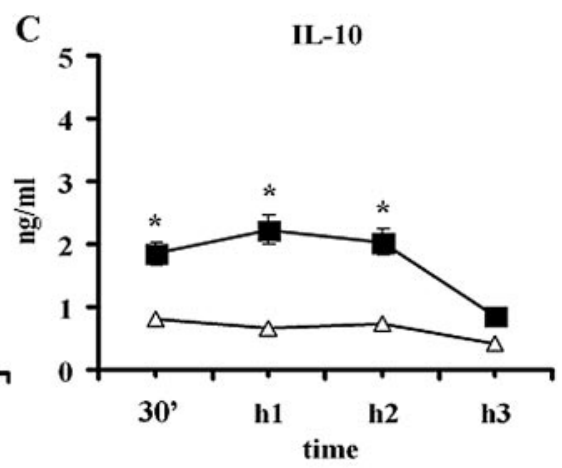

Fig. 4. KRN7000's effects on systemic release of cytokines by mice challenged with LPS. Mice challenged with LPS were injected with KRN7000 or vehicle at indicated times after challenge. Sera of 10 mice for each experimental group were collected $4 \mathrm{~h} \mathrm{for} \mathrm{TNF-} \alpha$ (B), $6 \mathrm{~h}$ for IFN- $\gamma$ (A), and $4 \mathrm{~h}$ for IL-10 (C) after challenge $(\square)$. Data reported are the means of serum cytokine content tested for each animal of any group. Open triangles $(\Delta)$ represent the values obtained from sera of mice treated with LPS plus vehicle at the same times of experimental groups. Serum cytokine levels were determined by ELISA. Data represented are the means of 3 different experiments. Before LPS challenge, the above cytokines were undetectable in the sera. Differences from cytokine levels detected in controls and experimental groups were reproduced without significant modifications when sera tested were collected at different time points after LPS challenge (data not shown). **, $P<0.001,{ }^{*}, P<0.05$. 

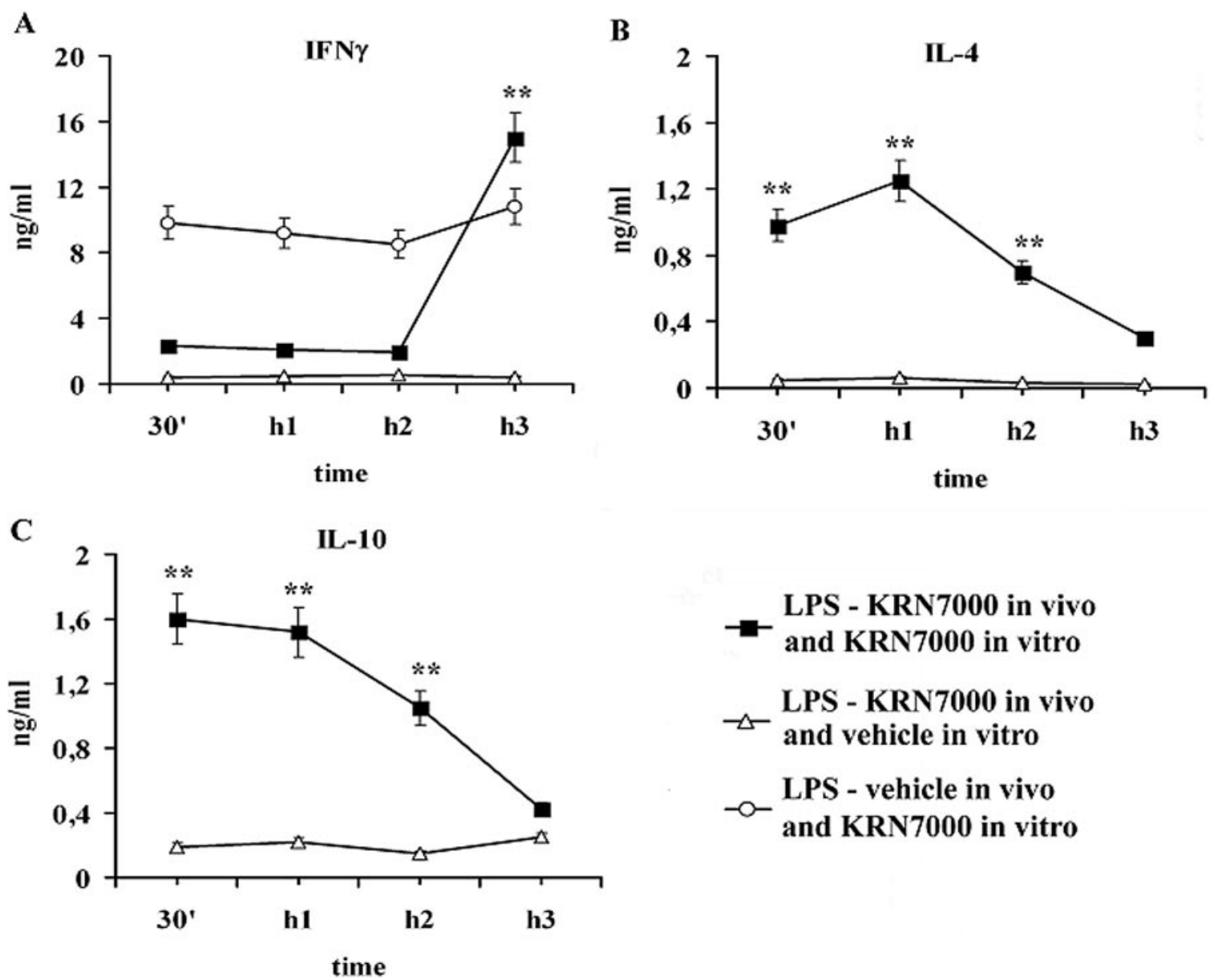

Fig. 5. KRN7000 in vitro reexposure induces poor IFN $\gamma$ but high IL-4 and IL-10 production by spleen cells from LPS challenged- $\alpha-$ GalCer-protected mice. C57BL/6 mice were injected at indicated times after LPS challenge with KRN7000 or with vehicle. One hour after $\alpha$-GalCer administration, groups of 10 mice were sacrificed. Pooled spleen cells from each group were cultured in complete medium with $10 \mathrm{ng} / \mathrm{ml}$ of $\mathrm{KRN} 7000(\square)$ or vehicle $(\Delta)$ for $60 \mathrm{~h}$ at $37^{\circ} \mathrm{C}$ in $5 \%$ $\mathrm{CO}_{2}$ atmosphere. IFN- $\gamma(\mathrm{A})$, IL-4 (B) and IL-10 (C) were measured in cultured supernatants by ELISA assays. Open triangles represent cytokine levels in mice primed, challenged with LPS, treated with KRN7000 and reexposed in vitro to vehicle. (A) Open circles ( $\bigcirc$ ) represent the levels of cytokines produced by splenocytes of mice primed, challenged with LPS plus vehicle, and reexposed in vitro to $\alpha$-GalCer. Results reported are the means of 3 different experiments. $* *, P<0.001$.

A

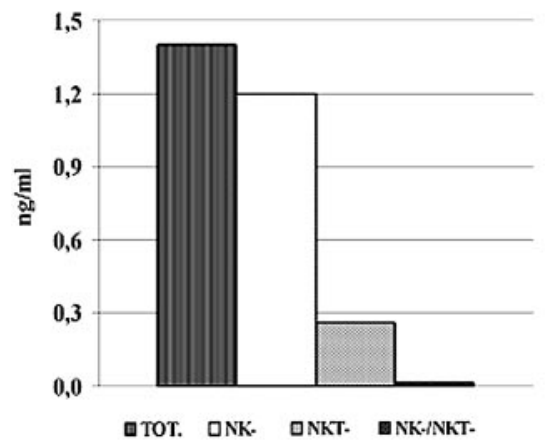

IL-4

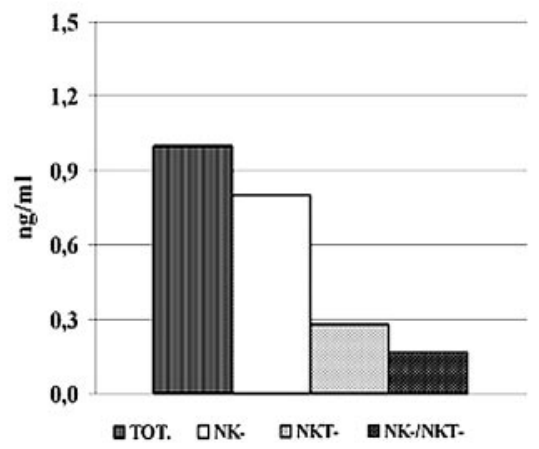

B

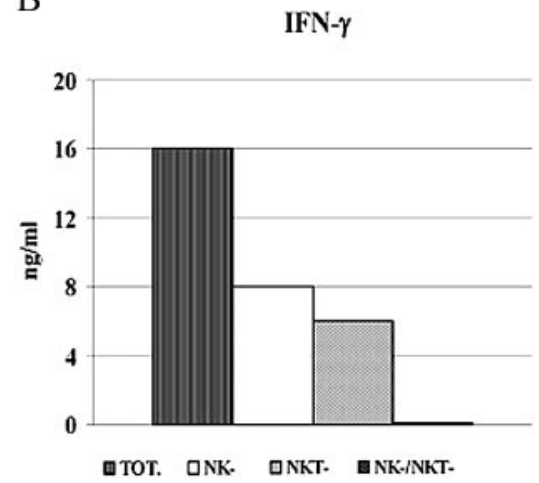

Fig. 6. Cytokine production by NKT-negative and NK-negative fractions of protected and nonprotected mice. Spleen cells from KRN7000-protected (A) or nonprotected mice (B) were depleted of NKT and/or NK cells by immunomagnetic methods. $\mathrm{NKT}^{-}$and $\mathrm{NK}^{-}$fractions were obtained from protected or nonprotected mice. $4 \times 10^{5}$ of separated or unseparated cells were reexposed in vitro to $\alpha$-GalCer or vehicle dissolved in complete medium for $60 \mathrm{~h}$ at $37^{\circ} \mathrm{C}$ in $5 \% \mathrm{CO}_{2}$ atmosphere. Cultured supernatants were tested for cytokines content by Quantikine ELISA kits. No significant difference in cytokines levels was detected testing both protected (treated with KRN7000 $1.5 \mathrm{~h}$ before challenge or $1 \mathrm{~h}$ after challenge) or nonprotected groups (treated $18 \mathrm{~h}$ before challenge or $3 \mathrm{~h}$ after challenge). Data shown are the means of 3 different experiments. 
TABLE 3. Effects of Anti-IL-10 on KRN7000-induced Protection by LPS Shock: Treatments Before LPS Challenge

\begin{tabular}{cccccc}
\hline \hline $\begin{array}{l}\text { Hours before LPS } \\
\text { challenge }\end{array}$ & Deaths/tested & Mortality $\%$ & AST U/L & $\begin{array}{c}\text { Percent of body } \\
\text { weight loss }\end{array}$ \\
\hline Positive controls $^{a}$ & $9 / 10$ & 90 & $538 \pm 101$ & $1154 \pm 307$ & $118 \pm 31$ \\
Negative controls $^{b}$ & $0 / 10$ & 0 & $129 \pm 30$ & $137 \pm 51$ & 0 \\
Negative controls $^{c}$ & $0 / 10$ & 0 & $146 \pm 36$ & $1151 \pm 255(253 \pm 57)^{*}$ & $7(1)$ \\
1 & $9 / 10$ & $90(10)$ & $720 \pm 101(263 \pm 33)^{*}$ & $407 \pm 46(226 \pm 28)^{*}$ & $10(0)$ \\
1.5 & $10 / 10$ & $100(10)$ & $442 \pm 151(241 \pm 28)^{*}$ & $545 \pm 45(231 \pm 56)^{*}$ & $9(1)$ \\
2 & $9 / 10$ & $90(10)$ & $635 \pm 85(235 \pm 49)^{*}$ & $242 \pm 26$ & 8 \\
10 & $10 / 10$ & 100 & $380 \pm 15$ & $448 \pm 16$ & 8 \\
\hline
\end{tabular}

Results shown were obtained with phenol-extracted E. coli LPS and reproduced using LPS from S. typhimurium or S. abortus equi. Two hours after challenge mice were bled and sera were collected by centrifugation for transaminases. Body weights were recorded before and $24 \mathrm{~h}$ after challenge. Data are represented as mean percentages of control body weight (100\%) over $24 \mathrm{~h}$. Data are represented as mean percent of control body weight (100\%) over $24 \mathrm{~h}$. All AST and ALT data represent mean values \pm SE obtained testing sera of 10 animals. Experiments were repeated 3 times with reproducible outcome. Normal range $( \pm 2$ SD $)$ AST $=$ 54-170 U/L; Normal range ALT $=32-114$ U/L. This range was obtained from a pool of sera obtained from sex- and age-matched C57BL/6. Data obtained from injecting $2 \mathrm{~h}$ before challenge isotype control mAbs i.p. (0.5 mg of rat $\mathrm{IgGl}$ dissolved in $0.2 \mathrm{ml}$ of PBS) are shown in brackets while data obtained injecting 0.5 $\mathrm{mg}$ of anti-IL-10 (JES5-16E3) are shown in bold. $* P<0.001$ by the $\chi^{2}$ test when data obtained from experimental groups were compared to control groups. ${ }^{a}$ Positive controls: LPS primed and challenged mice as reported in Materials and Methods. ${ }^{b}$ Mice were primed with LPS, as described in Materials and Methods, and $24 \mathrm{~h}$ later received $0.2 \mathrm{ml}$ of PBS i.v. ${ }^{c}$ Mice were injected with $0.2 \mathrm{ml}$ of PBS i.p. and $24 \mathrm{~h}$ later challenged with LPS, as described in Materials and Methods.

lenge (Table 6). Also, in these tables, data obtained injecting anti-IL-4 are shown in bold, whereas data obtained using control $\mathrm{mAb}$ are shown in brackets.

Thus, our results suggest that protection against systemic Shwartzman reaction due to KRN7000 is caused by an increase of IL-4 and IL-10.

\section{$\mathrm{NKT}^{+}-\mathrm{IL}-10^{+}$cells increase in KRN7000- protected mice whereas NKT ${ }^{+-} \mathrm{IFN}-\gamma^{+}$cells increase in a-GalCer-nonprotected mice}

NKT cells have a relevant but not well-defined role in the immunopathogenesis of the generalized Shwartzman reaction [18].

We next investigated whether in our model, NKT cells activated by LPS-KRN7000 in vivo, could be involved in cytokines production relevant for the protection by endotoxin shock.
It has been recently shown that in vivo exposure to KRN7000 down-regulated TCR expression on NKT cells leading to both intracellular IL-4 and IFN- $\gamma$ within $2 \mathrm{~h}$ of treatment, while from 6 to $72 \mathrm{~h}$ after $\alpha$-GalCer injection intracytoplasmic IL-4 in NKT was lost [23].

Taking into account previous described evidence, before testing intracellular cytokines in NKT in our model, we analyzed whether down-regulation of TCR in NKT occurs in LPStreated mice too. Spleen cells from controls and treated mice were stained with surface $\alpha \beta$ TCR mAbs vs. CDld/KRN7000 tetramers. We found a transient down-regulation of surface $\alpha \beta$ TCR in CDld/KRN7000-positive cells with a peak from 6 to $72 \mathrm{~h}$ of treatment with $\alpha-$ GalCer (data not shown).

To further explore the role of TCR down-regulated NKT in the production of Th2 cytokines, we stained spleen cells from protected or nonprotected mice by double intracellular staining for IL-10 and CDld/KRN7000 tetramers. Animals treated with

TABLE 4. Effects of Anti-IL-10 on KRN7000-Induced Protection by LPS Shock: Treatments After LPS Challenge

\begin{tabular}{|c|c|c|c|c|c|}
\hline $\begin{array}{l}\text { Hours after LPS } \\
\text { challenge }\end{array}$ & Deaths/tested & Mortality $\%$ & AST U/L & ALT U/L & $\begin{array}{l}\text { Percent of body } \\
\text { weight loss }\end{array}$ \\
\hline Positive controls ${ }^{a}$ & $9 / 10$ & 90 & $738 \pm 105$ & $1541 \pm 114$ & 10 \\
\hline Negative controls ${ }^{c}$ & $1 / 10$ & 10 & $119 \pm 33$ & $218 \pm 73$ & 1 \\
\hline 3 & $10 / 10$ & 100 & $346 \pm 12$ & $454 \pm 35$ & 11 \\
\hline 2 & $10 / 10$ & $100(0)$ & $510 \pm 83(258 \pm 11)^{*}$ & $751 \pm 95(241 \pm 16) *$ & $9(0)$ \\
\hline
\end{tabular}

Results shown were obtained with phenol-extracted $E$. coli LPS and reproduced using LPS from S. typhimurium or S. abortus equi. Two hours after challenge or 2 hours after $\alpha$-GalCer administration mice were bled and sera were collected by centrifugation for transaminases. Body weights were recorded before and $24 \mathrm{~h}$ after challenge. Data are represented as mean percent of control body weight (100\%) over $24 \mathrm{~h}$. All AST/ALT results represent mean values \pm SE obtained testing sera of 10 animals for experimental and control groups. Experiments were repeated 3 times with reproducible outcome. Normal range $( \pm 2$ SD) of AST $=54-170$ U/L, Normal range $( \pm 2 \mathrm{SD})$ of ALT $=32-114 \mathrm{U} / \mathrm{L}$. This range was obtained from a pool of sera obtained from sex- and age-matched C57BL/6 mice. Data obtained from injecting $2 \mathrm{~h}$ before challenge isotype control mAbs i.p. (0.5 $\mathrm{mg}$ of rat IgGl dissolved in $0.2 \mathrm{ml}$ of PBS) are shown in brackets; results obtained using anti-IL-10 (JES5-16E3) are shown in bold. $* P<0.001$ by the $\chi^{2}$ test when data obtained from experimental groups were compared to control groups. ${ }^{a}$ Positive controls: LPS primed and challenged mice as reported in Materials and Methods. ${ }^{b}$ Mice were primed with LPS, as described in Materials and Methods, and 24 hours later received $0.2 \mathrm{ml}$ of PBS i.v. ${ }^{c}$ Mice were injected with $0.2 \mathrm{ml}$ of PBS i.p. and 24 hours later challenged with LPS, as described in Materials and Methods. 
TABLE 5. Effects of anti-IL-4 on KRN7000-induced Protection by LPS Shock: Treatments Before LPS Challenge

\begin{tabular}{|c|c|c|c|c|c|}
\hline Positive controls ${ }^{a}$ & $9 / 10$ & 90 & $538 \pm 101$ & $1154 \pm 307$ & 9 \\
\hline Negative controls ${ }^{c}$ & $0 / 10$ & 0 & $246 \pm 36$ & $237 \pm 51$ & 0 \\
\hline 1 & $9 / 10$ & $90(10)$ & $480 \pm 95(263 \pm 13)^{*}$ & $985 \pm 155(253 \pm 27)^{*}$ & $8(1)$ \\
\hline 1.5 & $9 / 10$ & $90(10)$ & $462 \pm 80(241 \pm 38)^{*}$ & $820 \pm 120(226 \pm 48)^{*}$ & $11(0)$ \\
\hline 18 & $10 / 10$ & 100 & $1145 \pm 115$ & $1248 \pm 116$ & 8 \\
\hline
\end{tabular}

Results shown were obtained with phenol-extracted $E$. coli LPS and reproduced using LPS from $S$. typhimurium or $S$. abortus equi. Two hours after challenge mice were bled and sera were collected by centrifugation for transaminases. Body weights were recorded before and $24 \mathrm{~h}$ after challenge. Data are represented as mean percentages of control body weight (100\%) over $24 \mathrm{~h}$. Data are represented as mean percent of control body weight (100\%) over 24 h. All AST ALT results represent mean values $\pm \mathrm{SE}$ from five to eight animals. Experiments were repeated 3 times with reproducible outcome. Normal range $( \pm 2 \mathrm{SD})$ AST $=54-170 \mathrm{U} / \mathrm{L}$; normal range ALT $=32-114 \mathrm{U} / \mathrm{L}$. This range was obtained from a pool of sera obtained from sex- and age-matched C57BL/6. Data obtained injecting mice $2 \mathrm{~h}$ before challenge isotype control mAbs i.p. in animals $(0.5 \mathrm{mg}$ of rat IgG1 dissolved in $0.2 \mathrm{ml}$ of PBS) are shown in brackets, while results obtained injecting 0.5 $\mathrm{mg}$ of anti-IL-4 per mouse (11-B-11) are shown in bold. $* P<0.001$ by the $\chi^{2}$ test when data obtained from experimental groups were compared to control groups. ${ }^{a}$ Positive controls: LPS primed and challenged mice as reported in Materials and Methods. ${ }^{b}$ Mice were primed with LPS, as described in Materials and Methods, and 24 hours later received $0.2 \mathrm{ml}$ of PBS i.v. ${ }^{c}$ Mice were injected with $0.2 \mathrm{ml}$ of PBS i.p. and 24 hours later challenged with LPS, as described in Materials and Methods.

KRN7000 $1.5 \mathrm{~h}$ (protected) and $18 \mathrm{~h}$ (nonprotected) before challenge and mice treated $1 \mathrm{~h}$ (protected) and $3 \mathrm{~h}$ (non protected) after LPS challenge were chosen as representatives of different responses to KRN7000 in vivo treatments. Spleens were removed $1 \mathrm{~h}$ after elicitation for KRN7000-treated groups before challenge or $1 \mathrm{~h}$ after $\alpha$-GalCer administration in mice treated after challenge. Spleen cells from naive animals were stained as lymphocytes from experimental groups and called T0. Intracellular stainings with CDld/KRN7000 tetramers and anti IL-10 mAb (Fig. 7B) were compared with intracellular labeling with unloaded CDld tetramers and anti-IL-10 mAbs (Fig. 7A). IL-10-positive cells increased in mice treated $1.5 \mathrm{~h}$ before $(14.67 \%)$ or $1 \mathrm{~h}$ after challenge $(15.07 \%)$ when compared with naive controls $(2.35 \%$ in T0) or spleen cells from unprotected mice treated with KRN7000 $18 \mathrm{~h}$ before challenge $(4.08 \%)$ or $3 \mathrm{~h}$ after challenge $(5.11 \%)$ (A). In Fig. $7 \mathrm{~B}$, an increase of NKT-IL-10 double-positive cells was detected by higher percentages of CDld/KRN7000 tetramers and IL-10 intracellular stained cells when NKT from protected animals were compared with unprotected animals. In the spleen of mice protected by KRN7000 before challenge, $6 \%$ are NKT-IL-10 ${ }^{+}$ while in unprotected $2.7 \%$ are double-positive cells. This increase of NKT-IL-10-positive cells was also evident when KRN7000-induced protection occurred in mice treated with $\alpha$-GalCer after challenge $(7.01 \%$ in mice treated $1 \mathrm{~h}$ after challenge vs. $3.1 \%$ in mice treated $3 \mathrm{~h}$ after challenge).

FACS panels showed in Fig. 8B provide evidence that $\mathrm{NKT}^{+}$IFN- $\gamma^{+}$cells are increased in $\alpha$-GalCer unprotected mice. Mice were treated with KRN7000 or 1.5 and $18 \mathrm{~h}$ before challenge or 1 and $3 \mathrm{~h}$ after challenge. Animals were sacrificed $1 \mathrm{~h}$ after LPS challenge in groups treated with KRN7000 before challenge or $1 \mathrm{~h}$ after $\alpha$-GalCer administration in animals treated with KRN7000 after challenge. Spleen cells from naive animals were used as T0 controls and stained by the same

TABLE 6. Effects of Anti-IL-4 on KRN7000-Induced Protection by LPS Shock: Treatments After LPS Challenge

\begin{tabular}{|c|c|c|c|c|c|}
\hline Positive controls ${ }^{a}$ & $10 / 10$ & 100 & $438 \pm 105$ & $941 \pm 114$ & 10 \\
\hline Negative controls $^{c}$ & $1 / 10$ & 10 & $219 \pm 33$ & $218 \pm 73$ & 1 \\
\hline 3 & $10 / 10$ & 100 & $346 \pm 12$ & $454 \pm 35$ & 11 \\
\hline 2 & $10 / 10$ & $10(0)$ & $450 \pm 80(258 \pm 11)^{*}$ & $610 \pm 65(341 \pm 16)^{*}$ & $10(0)$ \\
\hline
\end{tabular}

Results showed in this table were obtained with phenol-extracted E. coli LPS and reproduced using LPS from $S$. typhimurium or $S$. abortus equi. Two hours after challenge or $2 \mathrm{~h}$ after $\alpha$-GalCer administration, mice were bled and sera were collected by centrifugation for transaminases. Body weights were recorded before and $24 \mathrm{~h}$ after challenge. Data are represented as mean percent of control body weight (100\%) over $24 \mathrm{~h}$. All AST/ALT results represent mean values \pm SE obtained testing sera of 10 animals for each group. Experiments were repeated 3 times with reproducible outcome. Normal range $( \pm 2$ SD) AST $=54-170$ U/L; normal range ALT $=32-114 \mathrm{U} / \mathrm{L}$. This range was obtained from a pool of sera obtained from sex- and age-matched C57BL/6 mice. Data obtained injecting mice $2 \mathrm{~h}$ before challenge isotype control mAbs i.p. (0.5 mg of rat IgG1 dissolved in $0.2 \mathrm{ml}$ of PBS) are shown in brackets, results obtained using anti-IL-4 (11-B-11) are shown in bold. $* P<0.001$ by the $\chi^{2}$ test when data obtained from experimental groups were compared to control groups. ${ }^{a}$ Positive controls: LPS primed and challenged mice as reported in Materials and Methods, and $24 \mathrm{~h}$ later received $0.1 \mathrm{ml}$ of PBS i.v. ${ }^{b}$ Mice were primed with LPS, as described in Materials and Methods, and $24 \mathrm{~h}$ later received $0.2 \mathrm{ml}$ of PBS i.v. ${ }^{c}$ Mice were injected with $0.2 \mathrm{ml}$ of PBS i.p. and $24 \mathrm{~h}$ later challenged with LPS, as described in Materials and Methods. 


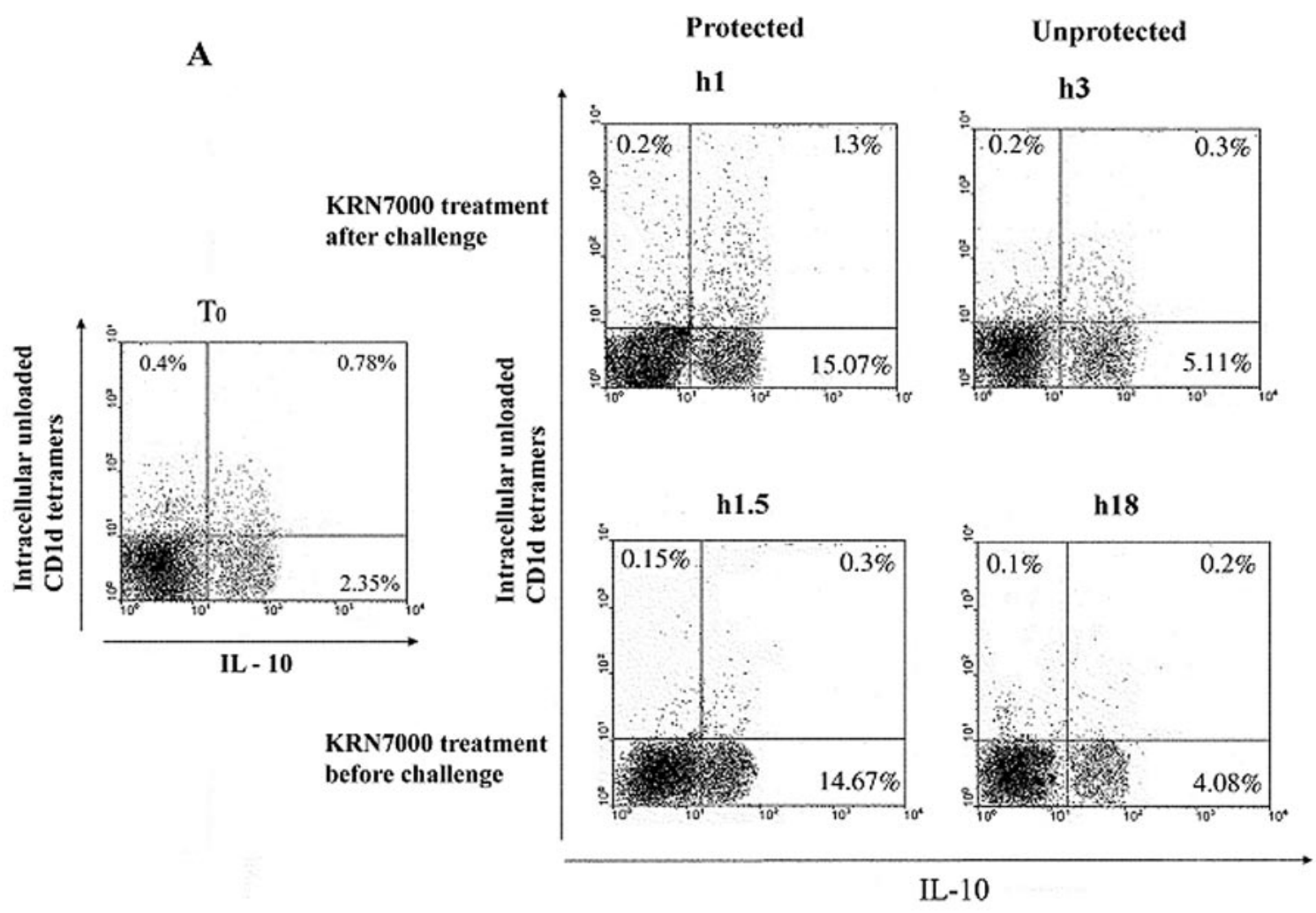

B

Protected

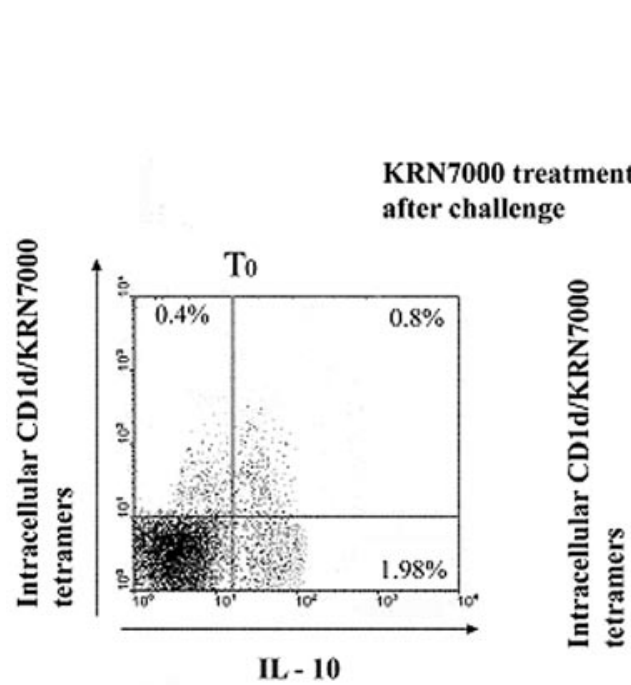

KRN7000 treatment before challenge
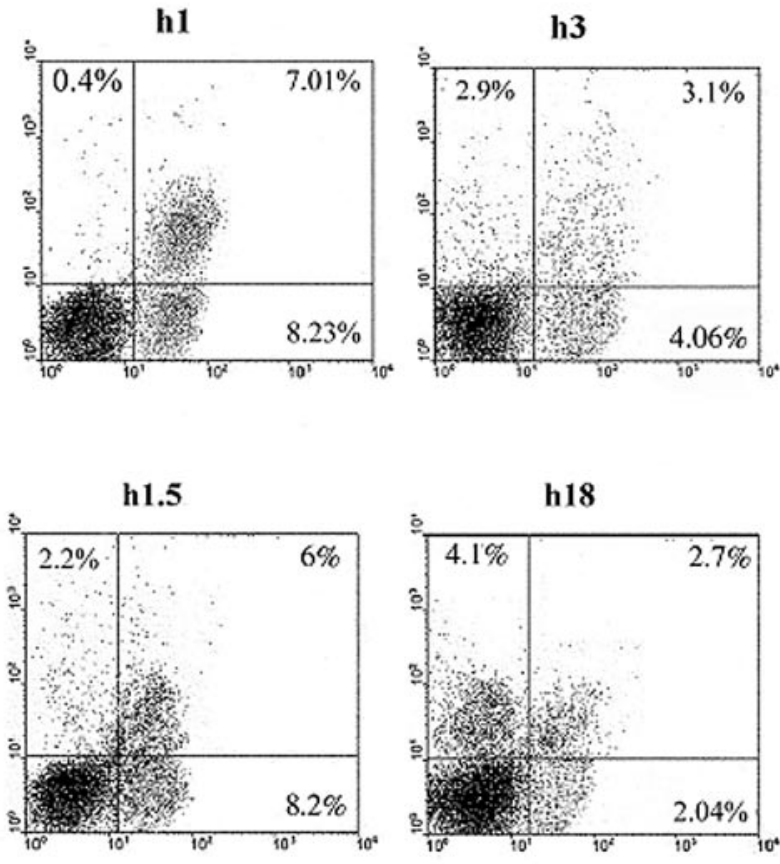

IL-10

Fig. 7. Reduction of IL-10-NKT double-positive cells in spleens of protected mice. Mice were treated with KRN7000 before or after LPS challenge at indicated times. They were sacrificed $1 \mathrm{~h}$ after elicitation (in groups treated with KRN7000 before challenge) or $1 \mathrm{~h}$ after $\alpha$-GalCer administration (groups treated with $\alpha$-GalCer after challenge). Spleen cells from protected ( $1.5 \mathrm{~h}$ before challenge and $1 \mathrm{~h}$ after challenge) or unprotected (treated $18 \mathrm{~h}$ before challenge and $3 \mathrm{~h}$ after challenge) mice were labeled with FITC-conjugated anti-mouse IL-10 and unloaded CD1d-PE-labeled (A) or CD1d/ $\alpha$-GalCer tetramers-PE-labeled intracellular double staining (B). Samples represented in panels signed $\mathrm{T}_{0}$ received the same staining procedure described for each panel, but the cells were obtained by sexand age-matched naive animals. Similar results were obtained in three different experiments. 
A

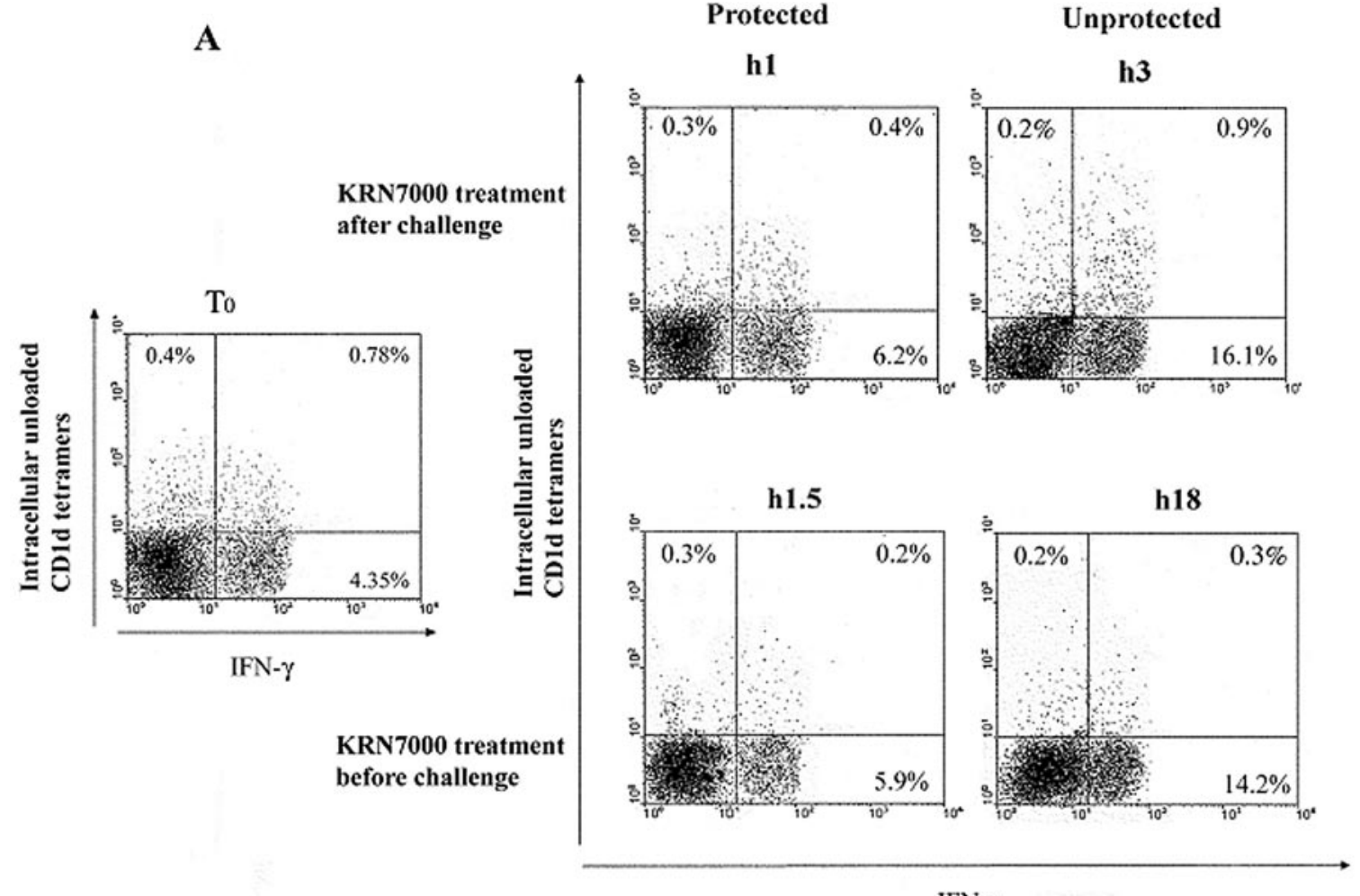

IFN-

B

Protected

Unprotected

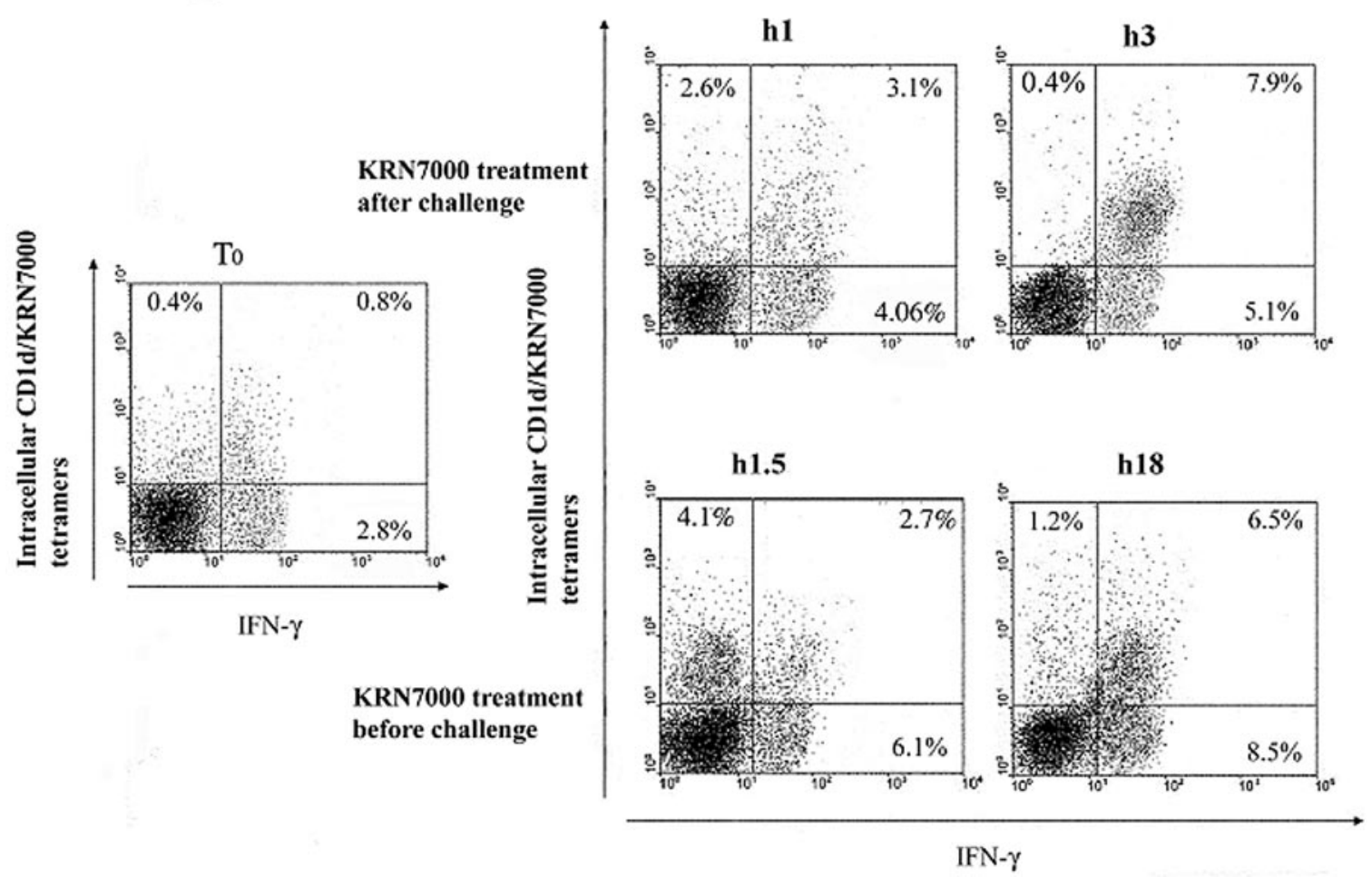

Fig. 8. Increase of IFN- $\gamma^{+}-\mathrm{NKT}^{+}$cells in spleens of unprotected mice. Mice were treated with KRN7000 before or after LPS challenge at indicated times. They were sacrificed $1 \mathrm{~h}$ after elicitation (in groups treated with KRN7000 before challenge) or $1 \mathrm{~h}$ after $\alpha$-GalCer administration (groups treated with $\alpha$-GalCer after elicitation). Spleen cells from protected ( $1.5 \mathrm{~h}$ before challenge and $1 \mathrm{~h}$ after challenge) or unprotected (treated $18 \mathrm{~h}$ before challenge and $3 \mathrm{~h}$ after challenge) mice were labeled with FITC-conjugated anti-mouse IFN- $\gamma$ and unloaded CDld-PE-labeled (A) or CD1d/ $\alpha-$ GalCer tetramers-PE-labeled intracellular double staining (B). Samples represented in panels signed $\mathrm{T}_{0}$ received the same staining procedure described for each panel, but the cells were obtained by sex- and age-matched naive animals. Similar results were obtained in 3 different experiments. 


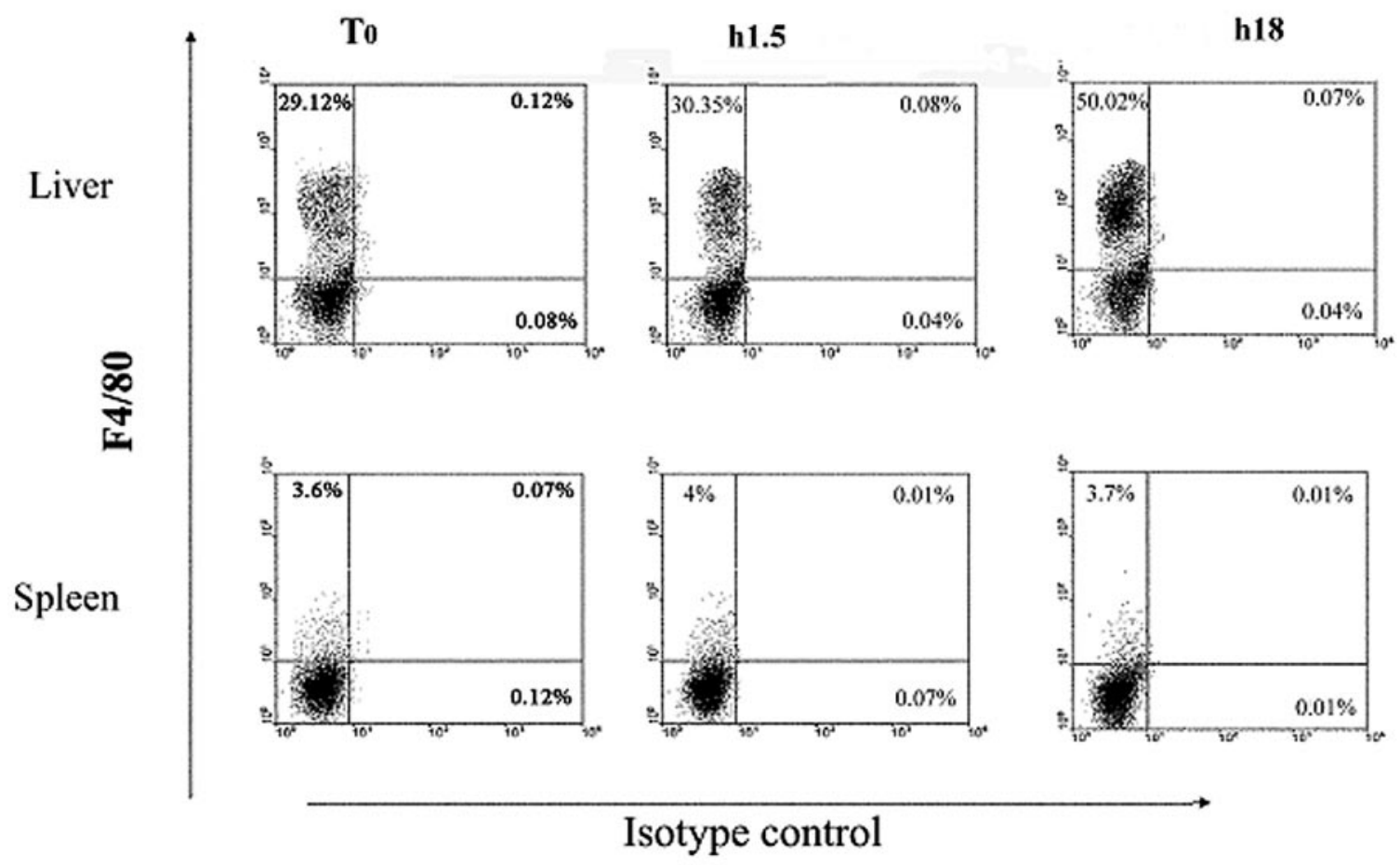

B

Protected

\section{h1.5}

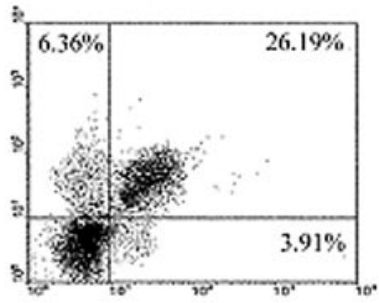

Liver

敨

Spleen
T0
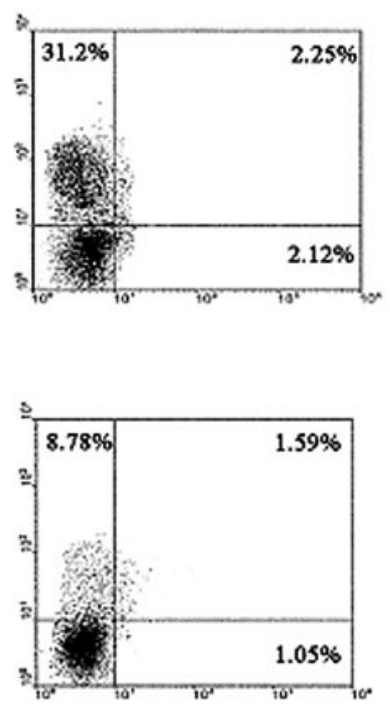

Unprotected

h18
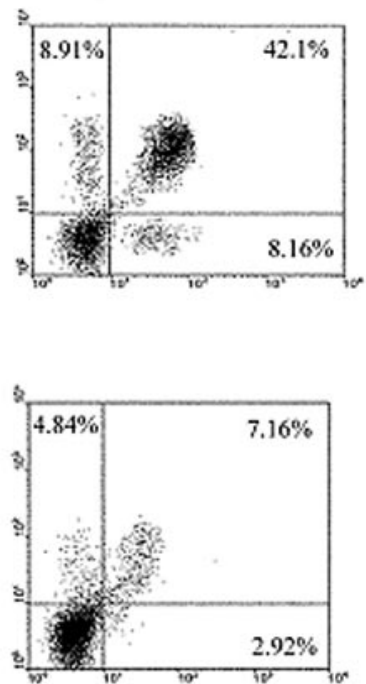

TNF- $\alpha$

Fig. 9. Liver and spleen machrophages with intracellular TNF- $\alpha$ in protected and nonprotected animals. Spleen and liver mononuclear cells from protected or nonprotected mice were incubated with anti-mouse CD16-CD32 for $5^{\prime}$ at $4{ }^{\circ} \mathrm{C}$ to block Fc bindings, followed by incubation with anti-F4/80-PE-labeled mAb. Cells were then fixed in PBS/paraformaldehyde. FITC-Rat IgG1, as isotype control (A) or anti-TNF- $\alpha-$ FITC-labeled mAbs (B) were used to detect cytokine content in permeabilized cells. Similar results were obtained in 3 independent experiments. Panels signed $\mathrm{T}_{0}$ received the same staining procedure, but the cells were obtained from sex- and age-matched naive animals. 
procedures used for experimental groups. Cells were stained with intracellular anti-IFN- $\gamma$ mAbs-FITC-conjugated and intracellular unloaded CDld-PE-labeled tetramers (Fig. 8A) or $\mathrm{CDld} / \alpha-$ GalCer tetramers (Fig. $8 \mathrm{~B}$ ) to detect $\mathrm{NKT}^{+}-\mathrm{IFN}-\gamma^{+}$ cells during LPS-KRN7000 treatments. More IFN- $\gamma^{+}$cells were detected in unprotected mice either when KRN7000 was injected before challenge $(14.2 \%)$ or when KRN7000 was injected after challenge $(16.1 \%)$, while low percentages of IFN- $\gamma^{+}$cells were detected in mice protected by KRN7000 either before challenge (5.9\%) or after challenge (6.2\%).

When these groups were stained with intracellular $\mathrm{CD} 1 \mathrm{~d} / \alpha-$ GalCer tetramers-PE-labeled and anti-IFN- $\boldsymbol{\gamma}$-FITC-labeled, we detected more NKT-IFN- $\gamma^{+}$either in groups of mice treated with KRN7000 before challenge $(6.5 \%$ in unprotected vs. $2.7 \%$ in protected animals) or in experimental groups treated with KRN7000 after challenge (7.9\% in unprotected vs. $3.1 \%$ in protected animals).

When intracellular IL-4 was tested in NKT, we found more NKT/IL-4 double-positive cells in protected than in nonprotected animals (data not shown). Almost the same differences between protected and nonprotected groups were obtained when liver mononuclear cells were analyzed (data not shown).

These data suggested to us that NKT cells are involved in the production of Th2 cytokines after short (within $2 \mathrm{~h}$ ) in vivo exposure to KRN7000 before and after LPS challenge, thus contributing to protection in Shwartzman reaction.

\section{Decrease of $\mathrm{F} 4 / 80^{+}$and $\mathrm{F} 4 / 80^{+}-\mathrm{TNF}-\alpha^{+}$in protected mice}

As TNF- $\alpha$ production was shown to be crucial for the pathogenesis of systemic Shwartzman reaction, we investigated whether more TNF- $\alpha$-producing macrophages $\left(\mathrm{F} 4 / 80^{+}\right.$. TNF- $\alpha^{+}$cells) were present in nonprotected compared with protected animals. Spleen- and liver-derived mononuclear cells from KRN7000-LPS-treated mice were therefore stained with a combination of surface F4/80-PE-labeled and intracytoplasmic TNF$\alpha$-FITC-conjugated mAbs (Fig. 9B), or an isotype control $\mathrm{mAb}$ for anti-TNF- $\alpha$ (Fig. 9A). As shown in Fig. 9B, the percentages of hepatic $\mathrm{F} 4 / 80^{+}-\mathrm{TNF}_{-} \alpha^{+}$cells were higher in nonprotected (42.1\%) than in protected animals (26.19\%), and a similar pattern of staining was observed in the spleen $(7.16 \%$ in nonprotected vs. $2.64 \%$ in protected animals).

In addition, we estimated (Fig. 10) the number of $\mathrm{F} 4 / 80^{+}$ cells during KRN7000 treatment before (A) and after endotoxin challenge (B).We detected higher numbers of machrophages in nonprotected $\left(4.5-5.5 \times 10^{5}\right.$ per liver) than in protected animals $\left(1-2 \times 10^{5}\right.$ per liver of $\mathrm{F} 4.80^{+}$cells). These data, combined with cytofluorimetric analysis (percentages of $\mathrm{F} 4 / 80^{+}$TNF- $\alpha^{+}$cells in liver and spleen), allowed us to calculate the absolute numbers of machrophages positive for intracellular TNF- $\alpha$ in the liver of protected or nonprotected mice: $\sim 2.6 \times$ $10^{4} \mathrm{~F} 4 / 80^{+}-\mathrm{TNF}-\alpha^{+}$cells per liver were counted in protected C57BL/6 mice, compared with $\sim 1.2-2.4 \times 10^{5}$ found in nonprotected ones.

These data suggested that a Thl cytokines-and/or chemokines-mediated change in the numbers of $\mathrm{F} 4 / 80^{+}-\mathrm{TNF}-\alpha^{+}$ cells in murine liver and spleen could be the cause of the KRN7000-modulated inflammatory responses culminating in endotoxin shock.
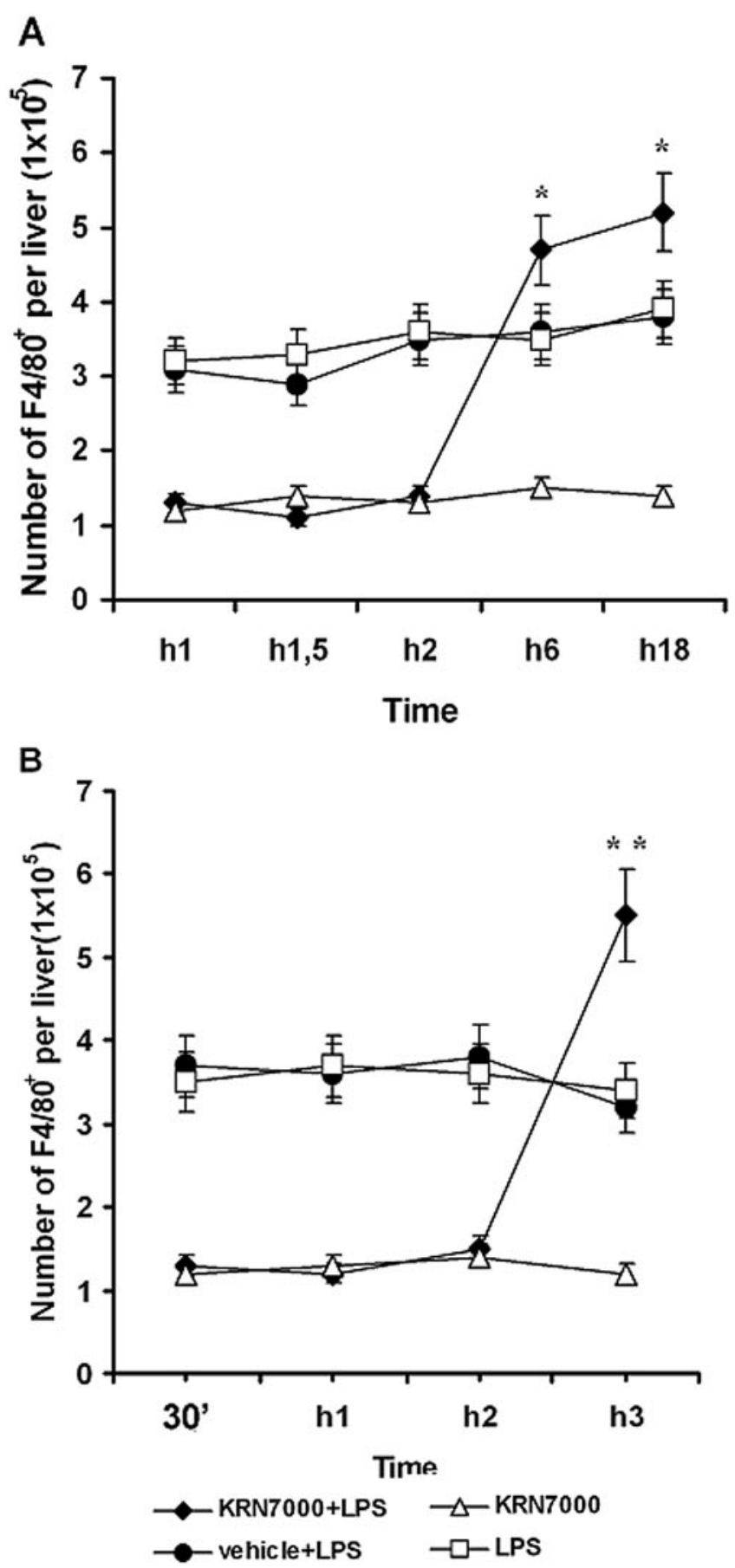

Fig. 10. Total number of liver F4/80 ${ }^{+}$cells in KRN700-LPS-treated mice. $\mathrm{F} 4 / 80^{+}$cells were separated $4 \mathrm{~h}$ after challenge from mononuclear cells obtained from livers using anti-F4/80-PE-labeled mAbs plus anti-PE-microbeads. Separation protocols and materials were furnished by Miltenyi. (A) Numbers of living $\mathrm{F} 4 / 80^{+}$cells obtained treating mice with KRN7000 before LPS challenge. (B) Mean values of living machrophages obtained by mice treated after endotoxin challenge. After immunomagnetic separations, cells were counted using $0.05 \%$ Trypan blue dye exclusion to include as experimental values only living cells. Each experiment was repeated three times. The differences in numbers from each experiment were less than $10 \%{ }^{*}, P<0.05$.

\section{DISCUSSION}

We hereby provide evidence that KRN7000 can exert protective effects against experimental systemic Shwartzman reac- 
tion. The novelty of our findings is that in vivo treatment with $\alpha$-GalCer when administered within $2 \mathrm{~h}$ before or after lipopolysaccharide challenge could modify a potent signaling pathway like that induced by LPS; moreover, KRN7000 causes direct damage to liver and, also through indirect effects on other immune cells, alters the response to endotoxin when administered early in the LPS challenge.

Protection from the endotoxin shock was achieved when mice were treated with KRN7000 within $2 \mathrm{~h}$ before and after LPS challenge. Interestingly, however, when KRN7000 was given $3 \mathrm{~h}$ after challenge or 6 to $18 \mathrm{~h}$ before challenge, we detected an increased production of IFN- $\gamma$ and, mostly important, no protection from the lethal Shwartzman reaction was achieved. KRN7000 is known to induce a cytokine storm, particularly in the liver [24]. It seems reasonable to speculate that treatment of mice with KRN7000, depending on the timing of in vivo exposure, results in the activation of NKT and, indirectly, of NK cells. This activation produced an increased ratio of IFN- $\gamma / \mathrm{Th} 2$ (IL-4 and IL-10) cytokines from 6 to $72 \mathrm{~h}$ of KRN7000 exposure [23]. In fact, when in vivo exposure occurred within $2 \mathrm{~h}$ from LPS challenge, NKT cells became Th2-polarized, while 3 to $18 \mathrm{~h}$ of exposure to $\alpha$-GalCer induced IFN- $\gamma$ production. In our model, the timing of Thl polarization after in vivo administration of KRN7000 (from 6 to $72 \mathrm{~h}$ ) confirmed the data of TCR down-regulation in NKT associated with the cytokines burst [23]. Our results confirm that temporal differences in interleukins production may potentially be a key event for the different types of responses to whom NKT are associated. For example, NKT cell responses requiring IL-4 and/or IL-10 production only occur within hours of NKT cell activation. This may limit the number and type of cells interacting with NKT cell-derived IL-4 and/or IL-10. In contrast, NKT cell responses requiring IFN- $\gamma$ production may evolve for subsequent hours/days and may influence the different cell types that encounter or remain in contact with NKT cells at later stages. It should be emphasized that NKT cells are thought to primarily act as initiators of immune responses involving downstream effector cells that also produce cytokines. IFN- $\gamma$, produced by NKT cells activated by in vivo treatment with KRN7000, could sequentially activate NK and other subsets that enhance IFN- $\gamma$ production. Smyth et al., who studied the antimetastatic effects of $\alpha$-GalCer, described a sequential production of IFN- $\gamma$ by NKT and NK [27]. KRN7000 could activate NKT and, indirectly, NK cells previously activated by LPS treatments. The reduced IFN- $\gamma$ production in NKT- and NK-depleted spleen cells from KRN7000-nonprotected mice implies the possibility that both cell types (NKT,NK), which contribute to Thl-driven pathogenesis of LPS-induced shock. The fact that NK cell-depleted C57BL/6 mice or mice that have their NKT-APC interaction blocked produce significantly reduced amounts of IFN- $\gamma$ and TNF- $\alpha$ when challenged with LPS compared with mice treated with LPS alone suggests that NK/NKT numbers and IFN- $\gamma$ / TNF- $\alpha$ are chief perpetuators of LPS shock [10].

Another possibility is that both NKT and NK cells, producing IFN- $\gamma$ and/or Th2 cytokines modulate endotoxin shock. This hypothesis is confirmed by two previous studies. Vinay et al. [10] described a model in which CD137-deficient mice, having reduced numbers and impaired functions of NK/NKT, are resistant to LPS-induced shock. In particular, Vinay et al. [10] observed that in wild-type mice, induction of septic shock was completely reversed by depletion of NK or blockade of NKT-APC interactions, strongly suggesting that a reduction of NK number and functions or defective NKT-APC interaction, significantly affect the outcome of endotoxin shock. These data therefore support this report and our and other studies previously published, suggesting that NK [25] and NKT [18] could play an essential role in Shwartzman reaction.

Matsuda et al. [22] found that KRN7000-treated naive animals produced IL-4 after $2 \mathrm{~h}$, while IFN- $\gamma$ was produced by naive mice $6 \mathrm{~h}$ after KRN7000 injection. As in Matsuda's paper, we found a different pattern of cytokine production depending on the time of KRN7000 exposure. It could be possible that short treatment induces transient interactions between NKT and APC. This cross-talk might be sufficient to activate Th2 genes transcription, but it couldn't be enough for secretion of IL-12 levels necessary to activate also NK cells, inducing IFN- $\gamma$ production. By contrast, longer exposure to NKT ligand induces more IL-12, activating also NK that contribute to the production of IFN- $\gamma$ in nonprotected animals.

The role of Th2-cytokines in the KRN7000-induced protection against disease is confirmed by experiments in which anti-IL-10 or anti-IL-4-neutralizing mAbs reverted protective effects by NKT ligand. These data are in agreement with previous findings $[28,29]$ demonstrating that endotoxin tolerance and subsequent survival were associated with an increase of IL-4 and IL-10 release.

The increased number of NKT cells producing Th2 cytokines (IL-4 and IL-10), detected either in spleen and liver of mice treated with KRN7000 before and after LPS challenge confirms that protection is accompanied by higher percentages of NKT producing IL-10 and IL-4. In particular, increased NKT-IL-10 double-positive cells after short (protective) $\alpha$-GalCer exposure is supporting published data about a model of KRN7000-induced hepatitis in which early mRNA for IL-10 and IL-4 in intrahepatic lymphocytes were detected [24].

Increased levels of IFN- $\gamma$ were associated to systemic release of TNF- $\alpha$. Moreover, IFN- $\gamma$ produced by KRN7000activated NKT and NK cells, could therefore contribute to the extent of LPS-induced macrophage activation. This activation is accompanied by an increased systemic release of TNF- $\alpha$, which is ultimately responsible for the endotoxic shock.

It was reported that $\alpha$-GalCer induces liver injury in C57BL/6 mice [24]. This tissue damage is characterized by an early release of plasmatic IL-4, IL-2, IL-6, and TNF- $\alpha$ (within $4 \mathrm{~h}$ from glycolipid injection) and a subsequent peak of IFN- $\gamma$ (after $12 \mathrm{~h}$ ) that is accompanied with increase of ALT (after $18 \mathrm{~h}$ of treatment). In another model [33], it was shown that NKT cells exposed in vitro to LPS, produce IFN- $\gamma$ in a dosedependent fashion. In our paper, time course of LPS-KRN7000 treatment provoking different effects on endotoxin shock could be due to opposing factors operating at different times. In the early phase of treatment (within $2 \mathrm{~h}$ before and after challenge), $\alpha$-GalCer could induce secretion only of Th2 cytokines (IL-4 and IL-10) that protect animals from endotoxin shock. LPS in protected animals isn't able to induce IFN- $\gamma$ release for at least three reasons: 1) in mice only primed, the dose of LPS is too low to induce IFN- $\gamma$ release after few hours, but at $6-18 \mathrm{~h}$ of, 
animals may also accumulate IL-12 released by LPS-activated machrophages and dendritic cells which, in turn, activates many NKT and NK to produce IFN- $\gamma ; 2$ ) either in primed or in challenged animals, after 3-18 h of $\alpha$-GalCer injection, there would be an exhaustion of the inhibitory effects of Th2 cytokines on TNF- $\alpha$ release and, consequently, an increased IFN- $\gamma$ production; 3) the time course of exposure to $\alpha$-GalCer necessary to have peak of plasmatic levels of IFN- $\gamma$ is $12 \mathrm{~h}$, although probably in challenged mice exposed to $400 \mu \mathrm{g}$ of LPS, $3 \mathrm{~h}$ of $\alpha$-GalCer exposure after elicitation could be sufficient to induce IFN- $\gamma$ production.

Because shock is LPS mediated, we next studied machrophages activation that plays a key role in the immunopathogenesis of Shwartzman reaction [1]. Macrophages that had intracellular "stores" of TNF- $\alpha$ increased in percentage and number, which thus contributed to the death of nonprotected animals. The increased number of F4/80-positive cells suggests that secretion of chemokines and expression of their relative receptors, responding to inflammatory molecules released during shock, could attract more macrophages to the sites of reaction like the spleen and liver. In fact, it has been shown by previous studies [31] that NKT cell-derived RANTES could recruit $\mathrm{F} 4 / 80^{+}$cells in inflamed tissues.

What is the role of TNF- $\alpha$ produced by NKT cells in the Shwartzman reactions or LPS toxicity? Injection of $\alpha$-GalCer and LPS may trigger both NKT cells and macrophages to secrete consistently increased amounts of TNF- $\alpha$, which is an important mediator of the Shwartzman reactions and has been reported to exert toxicity to liver cells, even in the absence of IFN- $\gamma[24]$.

As CDld molecules are nonpolymorphic and remarkably well conserved among species, the preferential induction of IL-4/IL-10 production through NKT activation and subsequent Th2-polarization suggest that KRN7000 may be an attractive immunomodulating agent useful for Thl-mediated severe diseases in humans.

In conclusion, our data suggest that KRN7000, activating NKT and indirectly NK, confers protection against the lethal manifestations of the experimental systemic Shwartzman reaction depending on the timing of in vivo exposure to KRN7000. When these subsets produce IFN- $\gamma$ and TNF- $\alpha$, the animals die, whereas IL-4 and IL-10 release seems to be responsible for protection. This KNR7000-mediated modulation of endotoxin shock strongly depends on the time of KRN7000 in vivo administration either in LPS-primed or -challenged mice. Probably, short $\alpha$-GalCer exposure is able to induce Th2 cytokines, while long exposure to NKT ligand induces Thl cytokines and sequentially NK-derived IFN- $\gamma$. This effect could depend by time of TCR of NKT activation, as it was suggested that "short" activation of NKT TCR induces Th2 cytokines, while longer TCR activation in NKT might be able to induce Thl cytokines [21, 22]. A deeper analysis on chemokines and their receptors in our model could be necessary to clarify the mechanism of tissue damage. Therefore, our study could provide useful insights for the design of immune modulation strategies based on treatments with natural and synthetic NKT ligands.

\section{ACKNOWLEDGMENTS}

We thank Dr. Yamano and Dr. Takamatsu (Kirin Brewery Ltd., Tokyo, Japan) for providing us with KRN7000. Authors are grateful to Dr. G. De Libero and H. M. Vordermeier for constructive criticism in preparation of this manuscript. G. S. was supported in this study by grants of "Ministero della Salute" (R6D060DNIM01).

\section{REFERENCES}

1. Hack, C. E., Aarden, L. A., Thijs, L. G. (1997) Role of cytokines in sepsis. Adv. Immunol. 66, 101-195.

2. Beutler, B., Cerami, A. C. (1989) The biology of chachectin/tumor necrosis factor- $\alpha$ as primary mediator of host response. Annu. Rev. Immunol. 7, $625-655$.

3. Beutler, B., Milsark, W. I., Cerami, A. C. (1985) Passive immunization against cachectin/tumor necrosis factor protects mice from lethal effect of endotoxin. Science 229, 869-871.

4. Heinzel, F. P. (1990) The role of IFN-gamma in the pathology of experimental endotoxemia. J. Immunol. 145, 2920-2924.

5. Doherty, G. M., Lange, J. R., Langstein, H. N., Alexander, H. R., Buresh, C. M., Norton, J. A. (1992) Evidence for IFN- $\gamma$ as a mediator of lethality of endotoxin and tumor necrosis factor- $\alpha$. J. Immunol. 149, 1666-1670.

6. Ozmen, L., Pericin, M., Hakimi, J., Wysocka, M., Trinchieri, G., Gately, M., Garotta, G. (1994) Interleukin-12, interferon- $\gamma$, and tumor necrosis factor $\alpha$ are the key cytokines in generalized Shwartzman reaction. J. Exp. Med. 180, 907-915.

7. Rothe, J., Lesslauer, W., Lotscher, H., Lang, Y., Koebel, P., Kontgen, F., Althage, A., Zinkernagel, R., Steinmetz, M., Bluethmann, H. (1993) Mice lacking the tumor necrosis factor receptor 1 are resistant to TNF-mediated toxicity but highly susceptible to infection by Listeria monocytogenes. Nature 364, 798-802.

8. Pfeffer, K., Matsuyama, T., Kundig, T. M., Wakeham, A., Kishihara, K., Shahinian, A., Wiegmann, K., Ohashi, P. S., Kronke, M., Mak, T. W. (1993) Mice deficient for the Kd tumor necrosis factor receptor are resistant to endotoxic shock, yet succumb to $L$. monocytogenes infection. Cell 73, 457-467.

9. Car, B. D., Eng, V. M., Schnyder, B., Ozmen, L., Huang, S., Gallay, P., Heumann, D., Aguet, M., Ryffel, B. (1994) Interferon gamma receptordeficient mice are resistant to endotoxic shock. J. Exp. Med. 179, 1437-1444.

10. Vinay, D. S., Choi, B. K., Bae, J. S., Kim, W. J., Gebhardt, B. M., Kwon, B. S. (2004) CD137-deficient mice have reduced numbers and function, are resistant to lipopolysaccharide-induced shock syndromes, and have lower IL-4 responses. J. Immunol. 173, 4218-4229.

11. Zeng, D., Gazit, G., Dejbakhsh-Jones, S., Balk, S. P., Snapper, S., Taniguchi, M., Strober, S. (1999) Heterogeneity of NK1.1 ${ }^{+}$T cells in the bone marrow: Divergence from the thymus. J. Immunol. 163, 5338-5345.

12. Ohteki, T., MacDonald, H. R. (1994) Major histocompatibility complex class I related molecules control the development of $\mathrm{CD} 4^{+} 8^{-}$and $\mathrm{CD} 4{ }^{-} 8$ subsets of natural killer $1.1^{+} \mathrm{T}$ cell receptor- $\alpha / \beta^{+}$cells in the liver of mice. J. Exp. Med. 180, 699-704.

13. Emoto, M., Emoto, Y., Kaufmann, S. H. E. (1995) IL-4 producing CD4 ${ }^{+}$ TCR $\alpha \beta^{\text {int }}$ liver lymphocytes: influence of thymus, $\beta_{2}$-microglobulin and NK1.1 expression. Int. Immunol. 7, 1729-1739.

14. Chen, Y., Chiu, N. M., Mandal, M., Wang, N., Wang, C. (1997) Impaired $\mathrm{NK}^{+}{ }^{+} \mathrm{T}$ cell development and early IL-4 production in CD1-deficient mice. Immunity 6, 459-467.

15. Mendiratta, S. K., Martin, W. D., Hong, S., Boesteanu, A., Joyce, S., van Kaer, L. (1997) CDldl mutant mice are deficient in natural T cells that promptly produce IL-4. Immunity 6, 469-477.

16. Smiley, S. T., Kaplan, M. H., Grusby, M. J. (1997) Immunoglobulin E production in the absence of interleukin-4-secreting CD1-dependent cells. Science 275, 977-979.

17. Heremans, H., Dillen, C., van Damme, J., Billiau, A. (1994) Essential role for natural killer cells in the lethal lipopolysaccharide-induced Shwartzman-like reaction in mice. Eur. J. Immunol. 24, 1155-1160.

18. Dieli, F., Sireci, G., Russo, D., Taniguchi, M., Ivanyi, J., Fernandez, C., Troye-Blomberg, M., De Leo, G., Salerno, A. (2000) Resistance of natural killer T cell-deficient mice to systemic Shwartzman reaction. J. Exp. Med. 192, 1645-1652. 
19. Kawamura, T., Takeda, K., Mendiratta, S. K., Kawamura, H., Van Kaer, L., Yagita, H., Abo, T., Okumura, K. (1998) Critical role of $\mathrm{NK}^{+}{ }^{+} \mathrm{T}$ cells in IL-12-induced immune responses in vivo. J. Immunol. 160, 16-19.

20. Bendelac, A., Killeen, N., Littmann, D. R., Schwartz, R. H. (1994) A subset of $\mathrm{CD}^{+}{ }^{+}$thymocytes selected by MHC Class I molecules. Science 263, 1774-1778.

21. Singh, N., Hong, S., Scherer, D. C., Serizawa, I., Burdin, N., Kronenberg, M., Koezuka, Y., Van Kaer, L. (1999) Activation of NK T cells by CDld and $\alpha$-Galactosylceramide directs conventional $\mathrm{T}$ cells to the acquisition of a Th2 phenotype. J. Immunol. 163, 2373-2377.

22. Matsuda, J. L., Gapin, L., Baron, J. L., Sidobre, S., Stetson, D. B., Mohrs, M., Locksley, R. M., Kronenberg, M. (2003) Mouse V $\alpha 14 i$ natural killer cells are resistant to cytokine polarization in vivo. Proc. Natl. Acad. Sci. USA 100, 8395-8400.

23. Crowe, N. Y., Uldrich, P. A., Kyparissoudis, K., Hammond, K. J. L., Hayakawa, Y., Sidobre, S., Keating, R., Kronenberg, M., Smith, M. J., Godfrey, D. I. (2003) Glycolipid antigen drives rapid expansion and sustained cytokine production by NKT cells. J. Immunol. 171, 4020-4027.

24. Biburger, M., Tiegs, G. (2005) Alpha-galactosylceramide-induced liver injury in mice is mediated by TNF-alpha but independent of Kupffer cells. J. Immunol. 175, 1540-1550.

25. Emoto, M., Miyamoto, M., Yoshizawa, I., Emoto, Y., Schaible, U. E., Kita, E., Kaufmann, S. H. E. (2002) Critical role of NK rather than V $\alpha 14^{+}$cells in lipopolysaccharide-induced lethal shock in mice. J. Immunol. 169, 1426-1432.

26. Hirschfeld, M., Ma, Y., Weis, J. H., Vogel, S. N., Weiss, J. J. (2000) Repurification of lipopolysaccharide eliminates signaling through human and murine Toll-like receptor 2. J. Immunol. 165, 618-622.

27. Smyth, M. J., Crowe, N. Y., Pellicci, D. G., Kyparissoudis, K., Kelly, J. M., Takeda, K., Yagita, H., Godfrey, D. I. (2002) Sequential production of interferon- $\gamma$ by NK1.1 ${ }^{+} \mathrm{T}$ cells and natural killer cells is essential for the antimetastatic effect of $\alpha$-galactosylceramide. Blood 99, 1259-1266.

28. Berg, D. J., Kuhn, R., Rajewsky, K., Muller, W., Menon, S., Davidson, N., Grunig, G., Rennick, D. (1995) Interleukin-10 is a central regulator of the response to LPS in murine models of endotoxin shock and the Shwartzman reaction but not endotoxin tolerance. J. Clin. Invest. 96, 2339-2347.

29. Margenthaler, J. A., Landeros, K., Kataoka, M., Eilers, M., Ku, G., Flye, M. W. (2003) Effects of endotoxin tolerance on propionibacterium acnes-primed lipopolysaccharide hepatic injury. J. Surg. Res. $112,102-110$

30. Brigl, M., Bry, L., Kent, S. C., Gumperz, J. E., Brenner, M. B. (2003) Mechanism of CDld-restricted natural killer $\mathrm{T}$ cell activation during microbial infection. Nat. Immunol. 4, 1230-1237.

31. Wilson, S. B., Delovitch, T. L. (2003) Janus-like role of regulatory iNKT cells in autoimmune disease and tumour immunity. Nat. Rev. Immunol. 3 , $211-222$. 